Historic, Archive Document

Do not assume content reflects current scientific knowledge, policies, or practices. 


$$
\text { (Y) }
$$




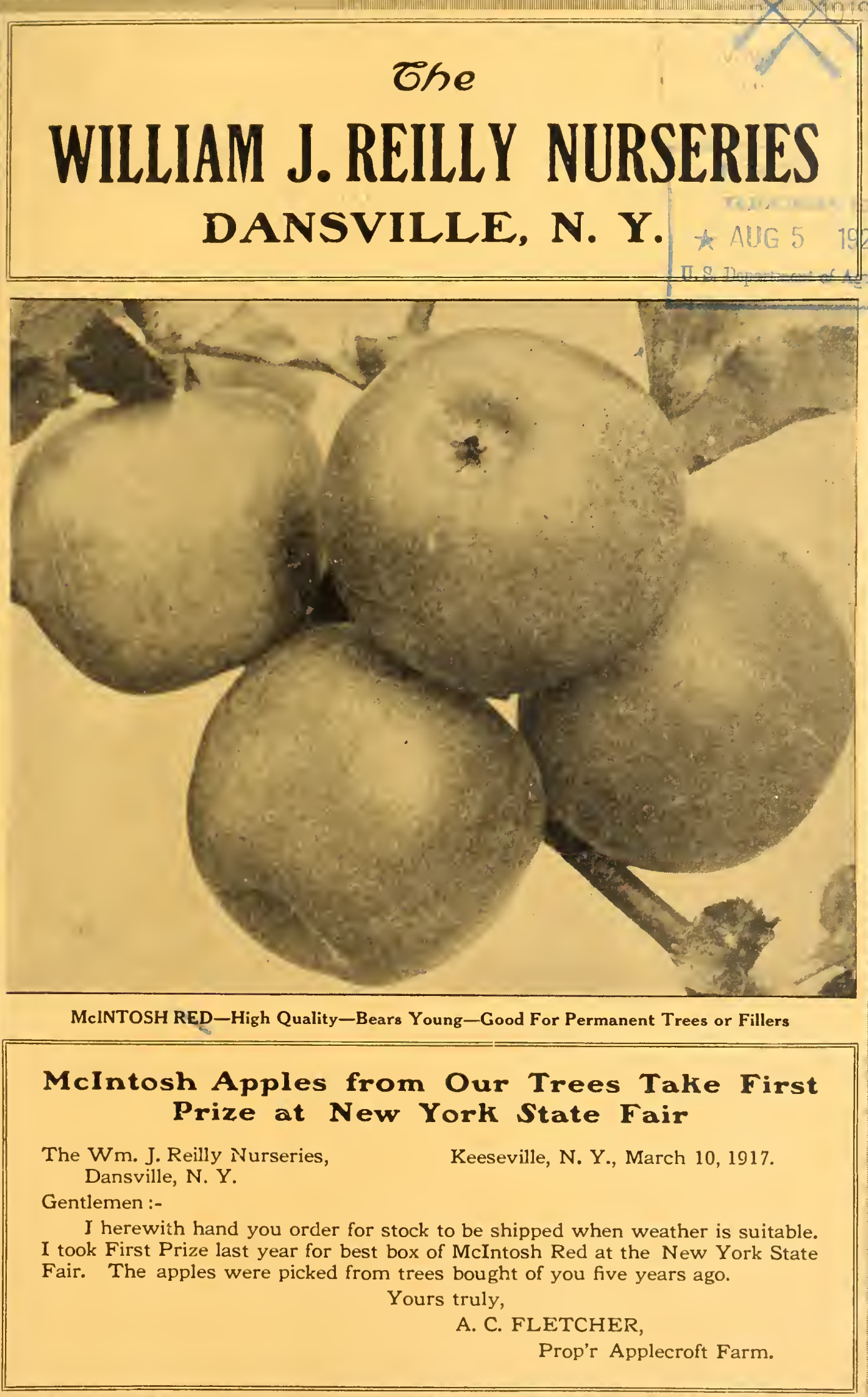




\title{
The William J. Reilly Nurseries
}

Originators of

“TREES AT HALF AGENT'S PRICES"

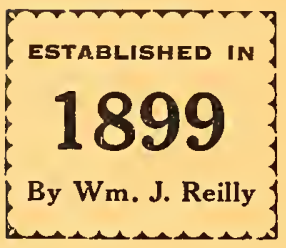

\author{
Members of \\ The American Association of Nurserymen, \\ New York State Nurserymen's Association, \\ Western New York Horticultural Society, \\ New Yo:k State Fruit Growers Association.
}

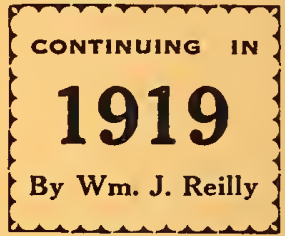

2

HIS is my twentieth year of uninterrupted growing of Nursery Stock. We have earned the confidence of the public by fair dealing and a close personal supervision of all departments under one head. This has made it possible for us to produce and sell a better grade of stock for less money than is possible under any other form of management.

There is a considerable shortage of salable Fruit Trees for this spring's shipping, owing to the limited quantity of Seedlings that the French Nurseries were able to supply in 1915 and 1916. The shortage of seedlings in France still continues, and the spring of 1919 will be the smallest planting of Fruit Tree Seedlings in the United States in the past 20 years. Prices have advanced of course, and they will go higher for at least three years to come.

Contract for this edition of our Catalog was let and paper ordered before peace was declared. We are conserving on paper, both in size of Catalog and number issued.

We specialize on Fruit Trees; growing them by the hundred thousand, and selling our entire product direct to the planter at Half Agent's Price. You can buy from this Catalog and your order will receive the same personal attention as though you came to the Nursery in person.

Sincerely,

WM. J. REILLY.

\section{SECURE VARIETIES NOW-PAY AT SHIPPING TIME}

If you want to secure certain varieties of trees and have not the ready cash to pay for the same, send us your order accompanied by a small remittance, just enough to show us you mean business, say one-fourth of the amount of your order, and we will book your orders and hold them for you until such time as you may want them shipped, when you can remit the balance. Orders placed with us early have the privilege of being shipped early if desired.

\section{WE GROW}

Fruit Trees by the Hundred Thousand

Budded from Bearing Trees
WE SELL

Direct to the Planter

At Half Agent's Price

Certified Stock Only (See Affidavit)

\section{WE GUARANTEE ALL STOCK TO BE}

First Class in every respect

Absolutely True to Name

Free from dangerous Insect and Disease

To reach destination in good condition 


\section{How to Order}

\section{Buy from the "Certified Grower" and Save Disappointment at Fruiting Time}

Send Cash with Order and save $50 \%$ on your trees. Why pay agents' expenses and commissions, the cost of collections or other people's bad debts. The middlemen between you and the grower can not and do not improve the quality of the trees.

Order Early as our orders are shipped in the rotation they are received-first come, first served. We cannot delay orders received first for those coming later that require immediate attention. If you want your order shipped on a certain date, mark it so on the order and we will get if off at that time if possible. Our regular shipping season begins about April 1st in spring and October 15 , in fall.

Packing Free. We make no charge for boxing, packing, or deilvering to freight station or express office. All orders are put up in boxes or bales, lined with heavy paper to guard against dry. ing sut. The trees and plants are packed in moist excelsior and straw.

References: Our old customers need none. To others would say that we are advertising in such papers as The Rural New Yorker, Farm Journal, Country Gentleman, American Agriculturist and others that guarantee their advertisers will give you a square deal. Our satisfied customers are our best recommendations, see a few of their letters in this catalog. We would also refer you to the Citizens Bank and Merchants \& Farmers Bank, both of Dansville, Dunn's or Bradstreet's Commercial Agencies.

Terms. Cash before shipment, if you wish to buy on other terms, state them, giving reference and responsibility. You need not, however, send full amount with your order, send one-fourth or ten per cent and the balance when shipment is wanted.

Special Rate. If your order amounts to $\$ 20.00$ or over net you may select all stock at 100 rates or lowest rates listed.

Discount. We will allow a special discount of $5 \%$ on all cash orders received before March 25 th. No discount after that date.

Remittance should be made by Bank Draft, Express Money Order, Post Office Money Order, Registered Letter or your own personal check.

In Ordering use the enclosed order blank and give full shipping directions. If Post Office address is different from railroad station be sure to give both. charge.

Agents' and Dealers' orders billed out and tagged for delivery to customers without additional

FREIGHT AND EXPRESS SHIPMENTS. From the service given by both Freight and Express last fall we feel perfectly safe in advising Freight shipment of Nursery Stock as during Peace time Government control together with a normal amount of shipping has put transportation service on a schedule time basis, and we can assure you of good service this spring. We guarantee stock to arrive at destination in good growing condition by either freight or express.

\section{We Prepay Freight on Cash Orders}

\section{Amounting to $\$ 5.00$ or over to the following states:}

$\begin{array}{lllll}\text { New York } & \text { Pennsylvania } & \text { New Jersey } & \text { Maine } & \text { New Hampshire } \\ \text { Massachusetts } & \text { Vermont } & \text { Connecticut } & \text { Ohio } & \text { Rhode Island } \\ \text { Illinois } & \text { Michigan } & \text { Maryland } & \text { Delaware } & \text { Indiana } \\ \text { Virginia } & \text { West Virginia } & \text { Kentucky } & \text { District of Columbia }\end{array}$

In all other states you may deduct $10 \%$ for transportation charges

EXPRESS SHIPMENTS-If you wish your stock shipped by Express instead of Freight deduct $10 \%$ from bill for transportation and pay the charges yourself on arrival. 


\section{Insist on YOUR Nurseryman Being a CERTIFIED GROWER}

$\left.\begin{array}{l}\text { STATE OF NEW YORK, } \\ \text { COUNTY OF LIVINGSTON, } \\ \text { TOWN OF NORTH DANSVILE }\end{array}\right\} \mathrm{S}$. S.

I, William J. Reilly, being duly sworn, do depase and say that I am a practical Nurseryman of twentyeight years experience in planting, propagating, dig ging and shipping Fruit Trees and other Nursery Stock. I also state that I am the sole owner and proprietor of THE WM. J. REILLY NURSERIES and that we are growing a HALF-MILLION FRUIT TREES and thousands of Ornamentals, Small Fruits and Roses.

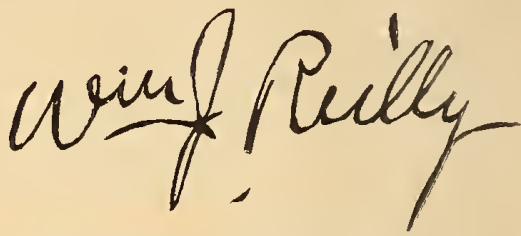

Subscribed and sworn to before me this 7 th day of January, 1919 .

E. R. WOODRUFF, Notary Public.

No. 1526 STATE OF NEW YORK

\section{DEPARTMENT OF FARMS AND MARKETS} DIVISION OF AGRICULTURE

\section{Certificate of Inspection of Nursery Stock}

This is to Certify that the stock in The Wm. J. Reilly Nurseries, of Dansville, County of Livingston, State of New York, was duly examined in compliance with the provisions of Section 305 of the Agricultural Law, and was found to be apparently free from all contagious and infectious disease or diseases, or the San Jose Scale or other dangerously injurious insect pest or pests. This certificate expires Sept. 1, 1919.

Dated Albany, New York, Sept. 5, 1918.

CHARLES S. WILSON,

Commissioner of Agriculture.

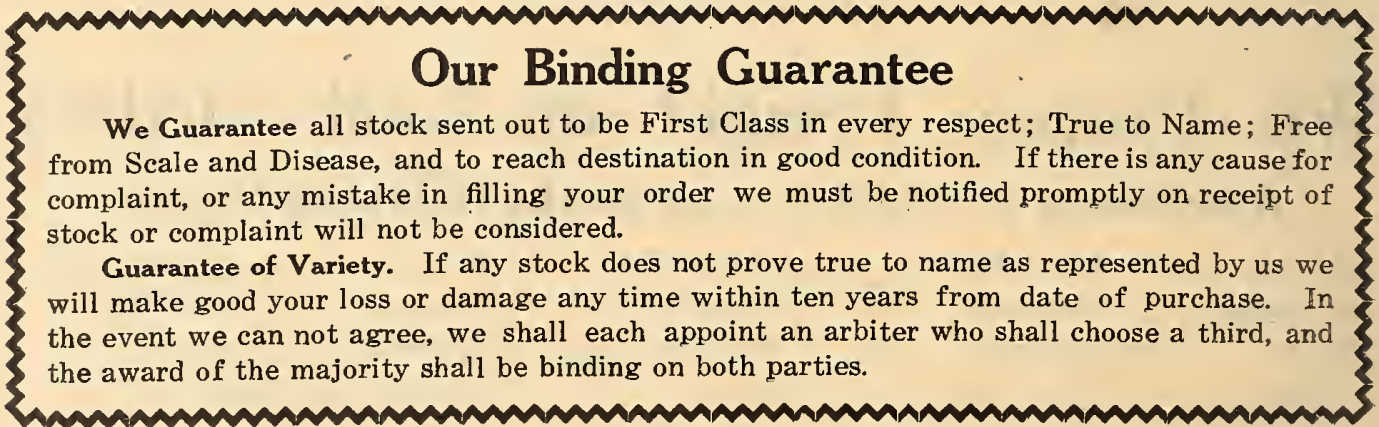

Save disappointment at planting time by ordering early this year.

Save disappointment at fruiting time by buying from the certified grower. 


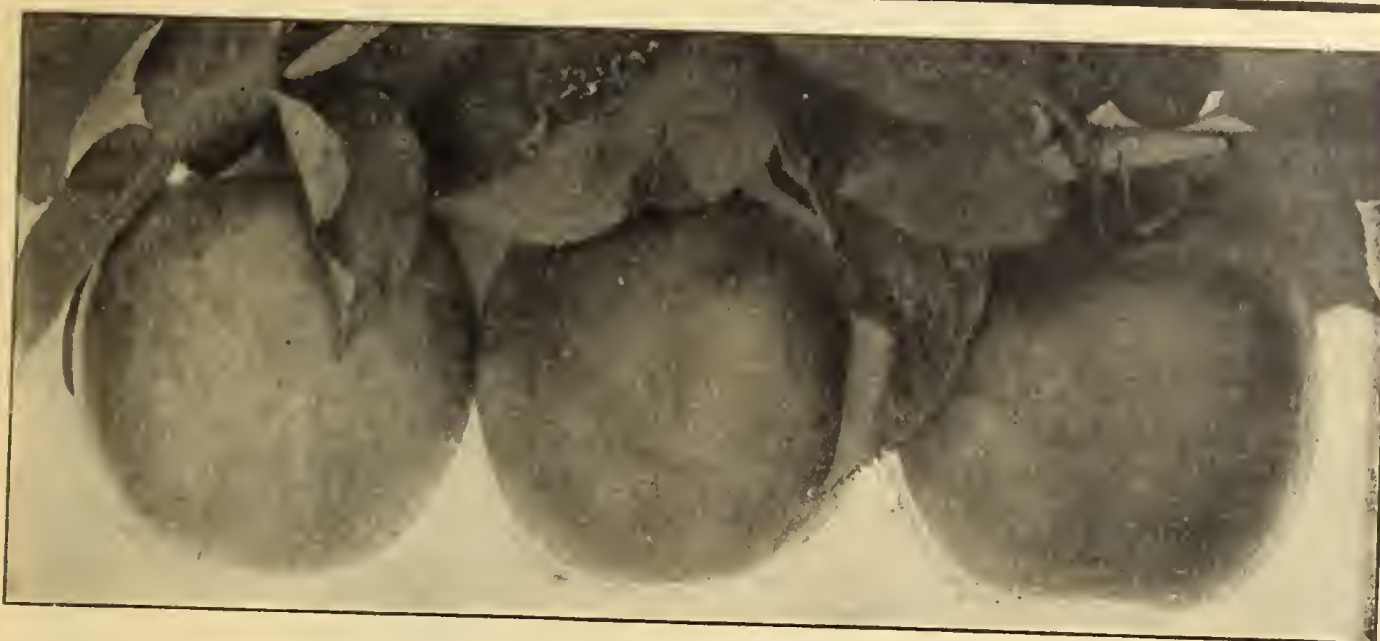

NORTHERN SPY

BALDWIN

\section{Apples}

The apple rightfully commands first place among our orchard fruits, unlike other fruits, its season of ripening is such that we can have apples nearly the year round.
The following list of varieties are grown in

cost of production, with but one profit added-" "The Grower's."

\section{Wholesale Price of all Varieties of Apple Trees Budded on Whole Root Seedlings}

\begin{tabular}{|c|c|c|c|c|c|c|}
\hline & & HEIGHI & CALIPER & $\mathrm{EACH}$ & IEN & HUMDRID \\
\hline $\begin{array}{l}X X X \\
X X \\
X \\
X X X\end{array}$ & $\begin{array}{llll}2 & \& & 3 & \text { Year } \\
2 & \& & 3 & \text { Year } \\
2 & \& & 3 & \text { Year } \\
1 & \text { Year }\end{array}$ & $\begin{array}{l}6 \text { to } 7 \mathrm{ft} \text {. } \\
5 \text { to } 6 \mathrm{ft} \text {. } \\
4 \text { to } 5 \mathrm{ft} \text {. } \\
3 \mathrm{ft} \text { \& up }\end{array}$ & $\begin{array}{c}34 \text { \& up } \\
4 / 8 \text { to } 31 \\
1 / 2 \text { to } 5 / 8 \\
\text { Stocky Buds }\end{array}$ & $\begin{array}{l}.43 \\
.38 \\
.33 \\
.43\end{array}$ & $\begin{array}{r}\$ 3.80 \\
3.30 \\
2.80 \\
3.80\end{array}$ & $\begin{array}{r}\$ 30.00 \\
25.00 \\
20.00 \\
30.00\end{array}$ \\
\hline
\end{tabular}

\section{Summer Varieties}

Early Harvest. Very early; not a good keeper; fruit medium size; pale yellow, tender, juicy, subacid. We recommend it for the home orchard because of $j$ ts merit as a cooking or dessert apple. Tree is a vigorous grover and bears young and regularly.

Early Strawberry. Striped and covered with deep red; flesh acid, crisp, aromatic. Tree moderate in growth; bears young.

Golden Sweet. A fine large light yellow apple. Tree spreading, vigorous and productive.

Red Astrachan. Very early. Medium size; yellow and red; flesh decidedly acid and juicy: it is an excellent cooking apple. 'l'ree very hardy and a good bearer. It is a good commer cial apple for local market on account of being very early.

Sweet Bough, Fruit large, pale yellow, tender and juicy; best early sweet apple. Tree compact grower, and abundant bearer.
Yellow Transparent Very early. This is one of the very best early summer apples to plant commercially, and one of the few varieties that is adapted to all of the apple growing districts. Tree a very young bearer and yjelds big crops every year. Fruit medium size, pale yellow; flesh tender, juicy, subacid, good. On account of it being a dwarfish grower it is a good variety for fillers in the regular orchard.

Williams Early Red. Medium size, dark red splashed with yellow. Flesh crisp, tender, juicy and subacid. Popular in New England where it brings a good price in the early apple market.

Liveland Raspberry. Medium to large size. Clear waxen white, striped with crinison. The flesh is snow white, tender, fine grained, stained with red; crisp, juicy, mild, almost sweet. Fine quality and regarded as one of the best of the early summer apples. Tree extremely hardy, healthy, vigorous and long lived. Good commercial variety; bears young; good filler.

\section{Trees Arrived in Good Condition Aller Being Three and a hall Weeks on the Road}

Valley View Farm, South Hadley, Mass., May 29, 1916.

Mr. Wm. J. Reilly. Dear Sir;-Just a line to tell you that all the trees we received are planted. Every Pear Tree (375) is alive and the Apples (950) look plump and vigorous, notwithstanding three and a half weeks they were on the road.
We have always understood that it was very inadviole

our XXX certainly seem to be hard and well grown a your XXX certainly seem to be hard and well grown, and we would never hesitate in recommending trees like those you sent us, Yours very truly, LEON F. WHITNEY. 


\section{Autumn Varieties}

Alexander. A Russian variety of very large size, with beautiful striped or stained red skin; crisp white flesh, tender, juicy and subacid. Tree a large and vigorous grower, bearing heavy crops.

Maidens Blush. Large size; pale lemon with crimson cheek; flesh white, tender and crisp; of good quality. Tree a vigorous grower and good bearer.

Oldenburg (Duchess of) Medium to Old large size; striped red and yellow; flesh white, juicy, of excellent flavor and fine quality. Tree hardy; of Russian origin and will stand the most severe winters; dwarfish grower; makes fine filler. This variety will thrive anywhere that apples can be grown. Good commercial variety.

Rambo. Medium size, red and yellow; mild flavor. Tree a strong and vigorous grower and good bearer.

Fall Pippin. Large size; yellow; flesh tender, rich and delicious. Valuable for culinary use and for market. The tree is a strong grower, hardy and long lived.

Gravenstein. An apple of large size, attractive appearance and excellent quality; one of the best of its season for home use and for market. Fruit red striped with yellow; crisp, juicy and fine flavored; always commanding a high price in the markets. It is extensively planted in New York and the New England states. Tree is very vigorous in growth, comes into bearing early, and bears good crops regularly.

Fameuse (Snow,) One of the finest Fameuse dessert apples; medium size; deep crimson color; flesh is snow white, tender, melting and delicious flavor. It is a valuable market variety in the northern apple growing districts. Tree a moderate grower; hardy, healthy and productive. Oct. to Jan.

Wealthy Late fall variety. Fruit Wealthy medium size; large if thinned; almost solid red color; flesh white; pleasant subacid, fine grained and very good. Splendid keeper but best in December and January. Orchardists who plant fillers between the permanent trees consider Wealthy one of the very best varieties. It is one of the most profitable market varieties and always brings good prices. Tree very hardy and a vigorous upright grower. This variety is valuable for cold climates on account of its hardiness, but succeeds in all of the apple districts.

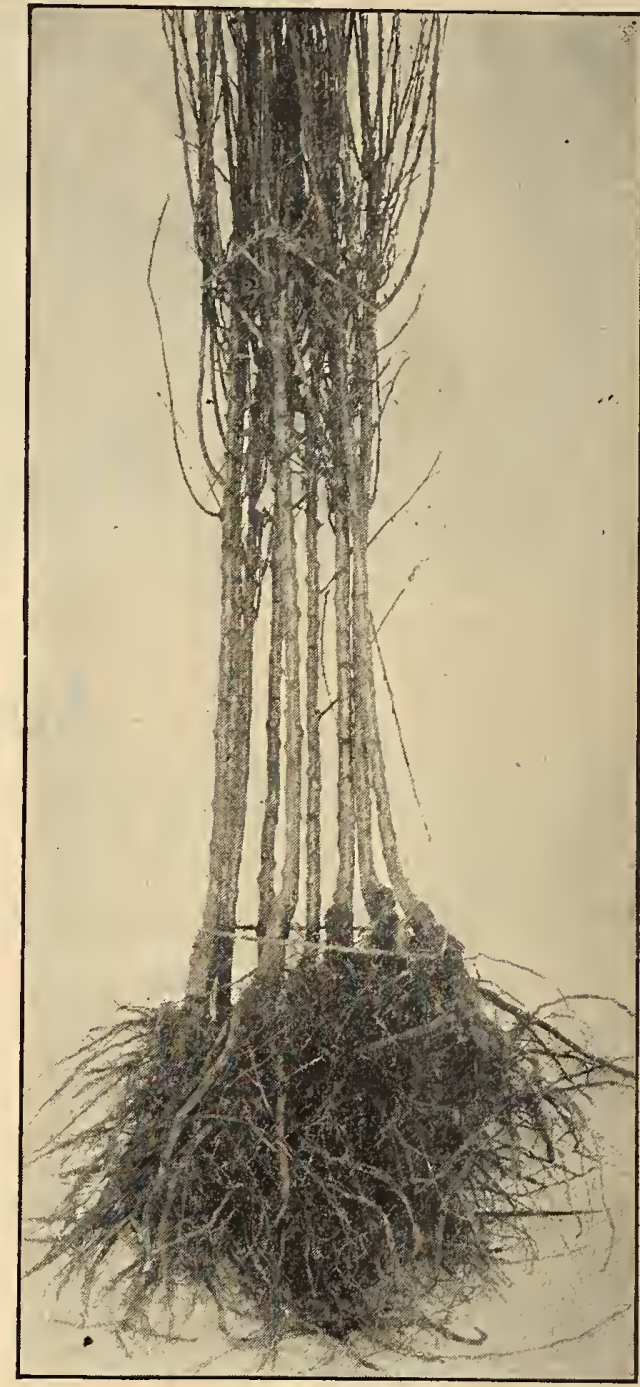

2 YEAR BUDDED APPLE ON FRENCH ROOTS

Note Regular Size top growth with double the ordinary root system.

TYPICAL UP-LAND GROWN

\section{GUARANTEED TREES atHalfAgéentsPrices

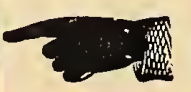 \\ When sending in your order be sure this Trade Mark is on the Return Envelope and Order Sheet. We are the Originators of Selling Direct to the Planter "TREES AT HALF AGENT'S PRICES" As there are other Nurseries of similar name in Dansville, be sure that you send your order and make remittance to \\ THE WM. J. REILLY NURSERIES}




\section{Winter Varieties}

Baldwin The standard market variety in the section from New England to Michigan and Virginia on the south. Fruit large, round, red all over; rich subacid flavor. It stands handling on account of its firm texture and thick skin. It keeps up well in storage and is one of the leading varieties used for export trade. Tree a strong grower, long lived and vigorous. Not as early a bearer as some varieties but enormeously productive.

Delicious This apple has been very ex-

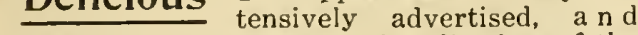
planted in all the apple growing districts of the country, and indications are that it is making friends wherever planted. 'T'he original tree in Iowa is reported to be still bearing enormous crops every year of high class fruit. The color is brilliant dark red shaded to yellow at the blossom end. The flesh is crisp, fine grained and juicy. Tree very hardy and vigorous grower. It should be in every orchard and garden.

Fallawater. Large, round, green with dull red cheek; coarse and of fair quality. Tree a strong grower and quite productive.

Golden Russet. (Bullock) Dull russet; flesh greenish, crisp, high flavored. Keeps until spring. Tree very hardy.

$\checkmark$ Hubbardston (American Blus h) large, round, pale red; mild, rich and tender. Quality of the best but not a long keeper. Adapted to the higher elevations of Pennsylvania, New York and New England. Tree a strong grower; bears well every year and comes into bearing young. Good commercial variety in its section.

Jonathan Medium size; brilliant red; fine grained, tender, sub acid. Keeps well without special care and stands handling well. Planted in a wide section of territory, but at its best south of New York state and in the west. Tree medium size of slender drooping habit; long lived but comes into bearing young and produces big crops every year.

King (Tompkins Co.) Uniform large King size; beautiful red and yellow; making a very attractive appearance; excellent in quality for either dessert or culinary use; flesh yellow, crisp and juicy. It is well adapted to marketing in fancy packages, and always at the top of market price. Tree is adapted to only certain sections; is subject to disease and not a big producer. In King sections it is the best apple that you can plant.

McIntosh Red Early winter variety. This is the leading ter markets. It is adapted to a wide range of territory, and does particularly well in all apple growing sections of the north and west. Large size; bright deep red; flesh white with pinkish tinge: juicy, with slightly acid flavor. Exceedingly attractive and the best eating apple of its season. Tree a medium grower and bears in three or four years after planting, makes fine fillers.
Banana Large to extra large; golden Bellow with beautiful pinkish blush; a fancy apple of choice dessert quality. Has a suggestive Banana flavor. For local trade it is often marketed in baskets at high price; it is not a long distance shipper as the skin is very thin. Every home orchard should have a few of this variety. Tree is a very strong grower and comes into bearing young.

Ben Davis. Best keeper known; large fine looking; yellow and red; flesh white, juicy, sub acid, coarse. Tree a strong grower, healthy and vigorous, bears young, annually and abundantly.

\section{Grimes Golden Medium size, golden} Arimes yellow; tender, rich, subacid flavor. It is an early winter apple but keeps until February without losing any of its crispness or rich flavor. It is a fine eating apple and splendid cooker. Not at its best in New York state, but very popular and profitable west and south. Tree a moderate grower; very hardy and productive; makes a good filler as it begins bearing young.

Gano. An improved Ben Davis, of better quality and deeper red color; stands shipping well and is a good keeper. Tree a strong grower and reliable cropper.

Northern Spy This variety is slow which is the only thing that keeps it from rank ing as the foremost variety in commercial importance. Its large size, fine quality and handsome appearance give it first rank for fancy trade. Large size; bright, light red and yellow; flesh juicy, crisp, rich and tender; fine flavor. When well grown and properly packed brings the very highest prices. Trees hardy, healthy and vigorous; a good variety to topwork other varieties on. A good way to plant Spy would be to plant them 40 feet apart and use some early bearing varieties as fillers.

Newtown Pippin. Large size; of excellent quality and a good keeper. It needs good soil and favored localities for paying results. Tree a medium grower; bears young and yields good crops annually.

Northwestern Greening. Large greenish yellow; good for dessert use; a good shipper and splendid keeper. It comes into bearing young but on account of blossoming early is liable to late spring frosts. Especially adapted to the middle Atlantic and New England states. Tree extremely hardy and vigorous.

Opalescent. One of the newer varieties that is well recommended by the New York state experiment station. It is large size, nearly covered with brilliant red on a yellow background. In quality it is excellent; should be grown for fancy trade to compete with the showy western fruit. Its season is rather short for a commercial apple, as it ends with January, but should prove a profitable early winter variety. Tree hardy, vigorous and productive.

Paragon. Very large brilliant red; an ex cellent keeper and fine for cooking. Comes into bearing when very young, and bears large crops annually. Tree is hardy and a good grower. 


\section{Rhode Island Greening This va- riety has} the distinction of being second in commercial importance in New York state, being surpassed by Baldwin only. Fruit large size, greenish yellow; flesh crisp, juicy, quite acid, of very fine flavor and quality. Ripens before Baldwin which extends the harvesting season. Tree is long lived and a spreading vigorous grower.

Rome Beauty Large size, uniform Rond smoth motled and striped in different shades of bright red; tender, juicy and good flavor. Of excellent keeping qualities. Appearance and size are its valuable points. A good grower; blooms late; bears heavily every year; is adapted to a wide range of soils, elevations and conditions, but does better on lighter soil than on heavy clay. This variety is at home in Ohio, Pennsylvania and West Virginia, and is being planted in other districts with good success. Very desirable for commercial planting both as permanent trees and as fillers.

\section{Staymans Winesap This is one} in of the leading commercial varieties in all apple districts outside of New York and New England. The fruit is medium to large; attractive green and yellow, almost covered with dark red stripes; flesh yellow, firm, crisp and juicy; quality fine. Tree a fast and large grower. Decidedly the best of the Winesap group.

Stark Fruit large size, round, greenish Stark yellow with red stripes; flesh yellow, crisp and mild sub acid; quality good. Stands handling well on account of its firm flesh and tough thick skin. Long keeper and a reliable commercial sort. It is a profitable variety throughout the entire Baldwin district, and we hear favorable reports beyond the range of profitable Baldwin cultivation. Tree an annual bearer and one of the strongest growers we have.

Smokehouse. Early winter variety. A large apple of fine flavor, excellent for eating; yellowish green mottled with dull red and with many russet dots; flesh firm, juicy, crisp and aromatic. Tree large, vigorous and a reliable producer.

St. Clairsville, O., Jan. 15, 1917
My orchards from your stock are doing
The Rome Beauties set out three
fine.
years last spring nearly all had from one
to eight apples on. Will send you an order
in a few weeks. With best wishes, I am,
Very truly yours,
A. L. BUMGARNER
A

Sutton Beauty. Medium to large, waxen yellow with a brilliant blush of red. Excellent flavor and a very superior high quality apple. Tree a medium grower and good producer.

Spitzenburg. Succeeds well in certain sections of the East, and is a standard variety in the West; produces fancy stock when well fed and cared for. Medium size, round; dark red almost all over; firm, crisp, subacid, slightly aromatic. One of the richest flavored of all apples, and very handsome. Spitzenbug can not be beaten when grown under the conditions it prefers. Be sure you are in the right location, then do not hesitate to plant it in any amount. Tree a moderate grower.

Tolman Sweet. Medium in size; pale yellow; sweet. Fruit much esteemed for pickling, boiling, baking and apple sauce. Tree is hardy, long lived and a good grower.

Twenty Ounce. Very large size, nearly round; yellow striped with red; flesh firm, rioh and sweet. Tree moderately vigorous; an early and heavy bearer. An early winter variety.

Wagener A high class apple of beautiagciner ful bright red color; fine texture; high flavor and excellent quality. It is one of the youngest bearers we have; we often find some fruit on our two and three year trees in the nursery row, and it has a tendency to over-bear in the orchard. Tree a vigorous upright grower, and on account of its early bearing habits and high quality makes a good variety to plant as fillers among permanent trees; perfectly hardy and succeeds anywhere that apples can be profitably grown.

Wolf River. Very large size, greenish yellow covered with crimson; half tender, spicy, subacid; fair quality but very showy. Fruit sells well on account of its large size and attractive appearance. Tree very hardy; vigorous grower and early bearer.

Winesap. Medium size; deep red; good quality. Has been a valuable commerical variety in the south and west, but is being supplanted by Staymans Winesap which is larger size and about as prolific a bearer.

York Imperial A very popular comof Pennsylvania; ranks the same in this section as Baldwin does in the North. Fruit greenish yellow overlaid with bright red stripes; flesh tender, firm, crisp, juicy and of good flavor; keeps well in storage. I'ree is a vigorous grower, strong and healthy, and an unusual heavy bearer.

Yellow Bellflower. Large size; pale yellow with red tinge on sunny side; tender; fine grained and excellent flavor. Tree moderately vigorous.

\section{Crab Apples}

Transcendent. Fruit very large; yellow striped with red. Juicy, crisp, and the best of the crabs for all purposes, and a valuable sort for cómmercial purposes. Bears young and produces immense crops annually. September and October.

General Grant. Large; yellow, striped with dark red, mild sub-acid. October.

Martha. Beautiful, glossy, yellow, shaded bright red, good size; mild, clear, tart. October.
Whitney. One of the largest, glossy green splashed with carmine; juicy and rich. Tree hardy and vigorous. August.

Hyslop. Large, deep crimson; one of the most beautiful of crabs; vigorous and hardy. October.

Yellow Siberian. Large; beautiful golden yellow. Tree a strong grower. September and October. 


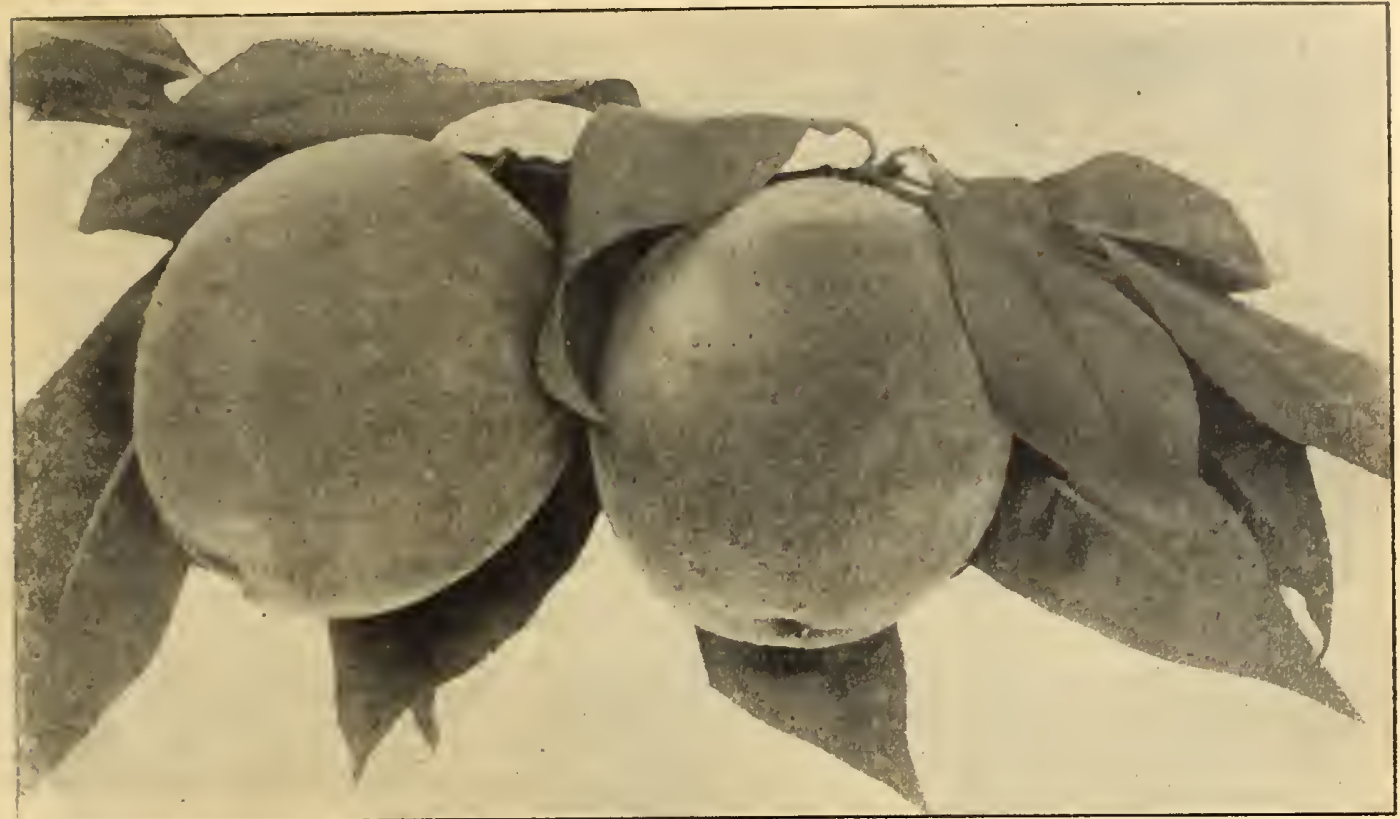

LATE CRAWFORD PEACH

\section{Peaches}

\section{All Budded on Tennessee Natural Pits, Free from Insects and Disease. Perfectly Healthy, Well Ripened Wood, with Splendid Fibrous Roots}

The Peach Tree requires a well drained, moderately rich soil, a warm sandy loam is probably the best.

In order to preserve the continued healthy growth of the tree and the fine quality of the fruit, the tree should have the shoots and branches shortened every year. so as to produce a round vigorous head with plenty of young wood. In trimming it should be borne in mind that the fruit is produced on the previous year's growth of wood; every spring the trees should be gone over and the new wood cut back about one-half, this will keep the tree well supplied with vigorous fruit buds and bearing wood. Clean culture, annual pruning, and frequent examination for borers are the requirements of the peach.

Prices of Peach-All One Year Trees

$\begin{array}{lllllrr} & & \text { HEIGHT } & \text { CALIPER } & \text { EACH } & \text { IEN } & \text { HLWNRED } \\ \text { XXX } & 1 \text { Year } & 5 \text { to } 6 \mathrm{ft} & 9 / 16 \& \text { up } & .40 & \$ 3.50 & \$ 25.00 \\ X X & 1 \text { Year } & 4 \text { to } 5 \mathrm{ft} & 7 / 16 \text { to } \% 16 & .35 & 3.00 & 20.00 \\ X & 1 \text { Year } & 3 \text { to } 4 \mathrm{ft} & 5 / 16 \text { to } 7 / 10 & .30 & 2.50 & 16.00\end{array}$

Rate -1 to 5 at each rate, 5 to 25 at 10 rate, 25 and over at 100 rate.

Belle of Georgia Fruit large size; flesh white, firm and highly flavored. This variety has become one of the standard varieties in the big commercial orchards, both North and South. Stands shipping well and brings top prices. In many respects it is equal to Elberta. Tree a rapid grower and very productive. Perfect freestone. Sept. 10.

\section{The New Hale Peach}

This new variety has probably been more extensively advertised than any other peach and from all reports and as far as we have been able to determine, it is deserving of all that has been said. The fruit as borne on our trees: Color is a deep yellow overspread with carmine; the skin is smooth with very little fuzz; the flesh is firm, fine grained and unusually solid; parts freely from the stone; the flavor is delicious. Ripens a few days before Elberta, but overlaps this kind by at least a week. This peach originated in one of the Georgia orchards of J. H. Hale, known as the Peach King of America.

We are the Originators of selling trees direct to the planter at "HALF AGENTS PRICE." Don't get us confused with Dealers, Retailers or Catalog=Middlemen. 
Champion Large size; creamy white Champion with a beautiful red cheek; flesh white; fine flavor, sweet, rich, juicy, freestone. It is a good shipper and sells for a high price. The tree is hardy and productive, and it is a valuable variety for either home or commercial planting. Aug. 25th.

Crawford Late One of the very best Crant commercial variety. Vorts, and a very splendid yellow with broad red cheek; flesh yellow, juicy and melting; high quality and rich flavor; freestone. Comes at a time when it is eagerly sought for canning and preserving, and brings the highest prices. It is considered by many to be the best of all late peaches, and being such a remarkable shipper it reaches market in prime condition. Tree a vigorous grower and a dependable producer of good crops of fruit almost every year. Sept. 20th.

Crawford Early. One of the standard early yellow peaches for commercial orchards and home use. Not as hardy in wood or bud as some of the early white sorts, but its high quality and fine flavor make it a favorite in its district. Freestone. Aug. 20th.

Chairs Choice. Extra large size; deep yellow with red cheek; flesh firm, sweet and rich. A good variety for general planting where a late peach is wanted. Tree a strong grower and good producer. Freestone. Ripens before Late Crawford.

Crosby. Sometimes called the frost proof peach, on account of its hardiness in wood and bud. Medium size, bright yellow splashed with carmine. Flesh yellow; good flavor. Tree a moderate grower. Freestone. Sept. 15th.

Captain Ede. Resembles Elberta and ripens just after it. An excellent shipper and a favorite for home use and canning; a profitable commercial variety. Tree strong, healthy and hardy. Freestone. Sept. 20th.

Engles Mammoth A handsome yelvery large size. Extensively planted in Michigan, and recommended by the State Experiment Station as the very best peach of its season; it comes at a favorable time; just before Elberta. Fruit large, round, yellow with red cheek; flesh yellow, sweet, rich and juicy; stone small. Tree very hardy, strong grower and productive. Freestone. Sept. 10th.

Fox Seedling. Large size; white and red; flesh white, melting, sweet high quality and good flavor. Good for home use, market and canning. Tree moderately vigorous and a regular bearer. Freestone. Sept. 25th.

Greensboro Many commercial growers Greensboro consider this to be the best of the early Peaches. Being somewhrt tender it requires care in handling, but reaches market when peaches are in strong demand. Fruit extra large for such an early peach; very handsome, rich, yellowish white with a crimson cheek; flesh white, tender and of fine quality. Tree a strong grower and extremely hardy in both wood and bud; we recommend it for planting in cold sections where other varieties do not succeed. Semi-cling. Aug. 5th.

Globe. Very large size; rich golden yellow, with a red blush; flesh yellow, firm, juicy and rich; good quality. Tree hardy and a good bearer. Freestone. Sept. 20.
Smock (Beer's Smock) Fruit medium to large size; bright orange yellow beautifully blushed with deep red; the flesh is firm, tender, juicy and of fine flavor. One of the old standard varieties, that is still very valuable for home use and for market. Tree a strong grower and productive. Freestone. Sept. 30th.

Wager. Medium size; red and yellow; juicy and fine flavored. Tree hardy and productive. Freestone. Sept. 10th.

Yellow St. John. Medium to large size; beautiful yellow, flushed on the sunny side with brilliant deep crimson; flesh yellow, tender, juicy and of extra fine quality. A good early yellow market peach, coming at a time when the demand is at its best. Somewhat tender, and requires careful handling and packing to reach market in good condition. The tree is a good grower and bears heavy crops every season. Freestone. Aug. 15th.

Stump. Large size; round; skin clear white with a brilliant red cheek; flesh white, tender, juicy and of fine flavor. One of the old varieties that is still popular. The tree is a strong vigorous grower and produces big crops. Freestone. Sept. 15th.

Stephens Rareripe. Fruit medium size; white, shaded red; flesh white, firm, juicy, superior quality. Tree productive and free from disease. Freestone. Sept. 10th.

Triumph. One of the very best of the real early yellow peaches. Fruit good size, yellow and red; flesh yellow; fine flavor for so early a. peach. Tree a very strong grower and good bearer. Freestone. Aug. 5th.

Wonderful. Large, and uniform in size and shape. Rich golden yellow nearly covered with bright crimson. Flesh yellow, rich and highly flavored. The tree is strong and vigorous and noted for its heavy crops. Freestone. Oct. 10 th.

Farmington, Iowa, May 2, 1917.

The Wm. J. Reilly Nurseries,

Gentlemen:-I am wonderfully well pleased with my 700 Peach trees in quality, promptness and price.

Yours very truly, H. L. DibBle.

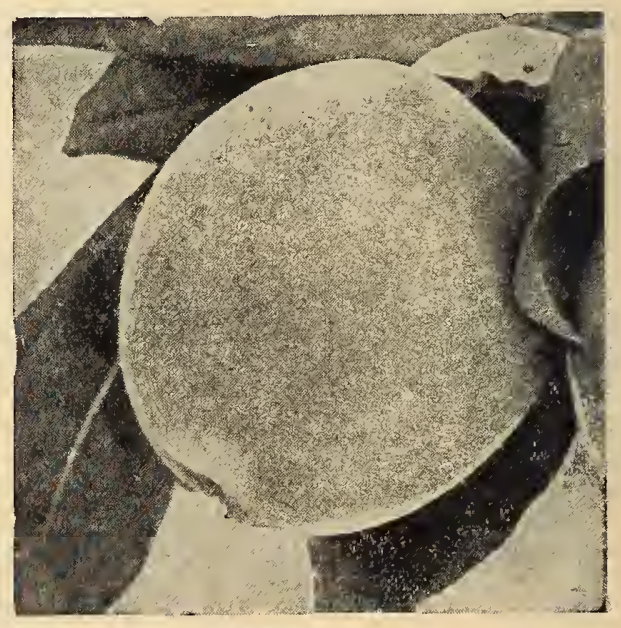

GREENSBORO 
Elberta The leading market variety in all peach growing sections; it seems to thrive wherever pedches can be grown; it is safe to say that one-third of all peaches planted are Elberta. Fruit large to extra large; golden yellow with brilliant shades of red; firm, juicy, rich and sweet. Tree vig. orous, hardy, and thrives in the entire peach growing section. For years Elberta has been the standard market peach in both northern and southern markets. No other peach has ever been introduced that fills all the requirements of a commercial peach like Elberta. Freestone. Sept. 15-20.

Fitzgerald. Large size; golden yellow with red cheek; flesh yellow tinted with red at the pit; juicy and of good quality. Tree medium grower and very productive; bears young. Originated in Canada and is one of the hardiest peaches in both wood and bud. Profitable for market and should be planted where hardy varieties are necessary. Freestone. Sept. 5th.

Gold Drop. Planted commercially in Michigan, but not well known in other sections. Fruit medium size, golden yellow; flesh yellow. Tree hardy and a young and heavy bearer. Profitable for market and a good variety for home orchard. Freestone. Sept. 15th.

Hills Chili. Fruit medium size, dull yellow; flesh yellow. Tree very hardy, and a sure cropper. Especially desired for canning. Freestone. Sept. 20th.

Hiley. Fruit large size with a delightful red cheek; flesh is white, tender and exceedingly juicy. A good shipper for an early peach, and brings good prices. Tree hardy in wood and bud; a strong grower and good producer. Freestone. Aug. 30th.

Heath Cling. Large creamy white with faint blush of red; tender, juicy, melting and luscious. Excellent for canning and preserving. An old well known variety that always commands fancy prices. Clingstone. Oct. 5th.

Iron Mountain. Extra large, creamy white with red cheek. A New Jersey variety that is meeting with success in New York orchards. Freestone. Sept. 25th.

Kalamazoo. Large size, golden yellow with crimson cheek; flesh yellow, very good, sweet and mild. Strong grower, early bearer, hardy and productive. Freestone. Sept. 15th.

Krummel, Large, golden yellow, blushed with carmine. Flesh yellow, tinted red at the pit ; firm, melting, rich, subacid. Good quality. A good keeper and shipper. The tree is hardy, healthy, and a strong, vigorous grower. One of the best late peaches. Freestone. Oct. 5th.

Mountain Rose. Fruit large, round; white and red; flesh white; juicy, rich, tender and sweet. The fruit is firm, solid, and a good shipper. This is one of the old varieties that on account of its size, quality and beauty still retains its popularity. Freestone. Aug. 25th.

Niagara A new variety of unusual large Fruit a beautiful size and attractive appearance. brilliant red; flesh y ellow, tender, rich and juicy, ripening clear to the pit. Resembles the Crawford but larger, better quality, and a better bearer. It has been thoroughly tested by extensive orchard planting in western New York where it originated, and found to be an excellent commercial variety. The tree is a good strong vigorous grower and very hardy; bears young and regular. Freestone. Sept. 1st. (See colored photograph on back cover.)

Old Mixon Free. Fruit large, pale yellow with good red cheek; flesh white with red stain at the pit; tender rich and excellent. Tree a good grower and productive. Freestone. Sept. 10th.

Reeves Favorite. Fruit large to extra large: round; yellow with beautiful red cheek; flesh deep yellow; red at the pit; juicy and of excellent flavor. Tree fine and large, bears heavy and regular. Freestone. Sept. 25th.

Ray. One of the new varieties that gives promise of becoming popular, we offer it this year for the first time. Fruit large size, greenish white deeply tinted with erimson; flesh white, firm, good quality; an excellent shipper and keeps well. Trees are strong growers. Sept. 10th.

Salway Fruit large, handsome yellow frm, juicy and rich: particularly fine for yellow, ning and preserving. Comes on the market very late and is valuable where a succession is desired. Good keeper and shipper. Tree haruy, healthy and good bearer. Freestone. Oct. 10th. 


\section{Pears}

The cultivation of this noble fruit is extending as its value is appreciated. The range of varieties is such that, like apples, they can be had in good eating condition from August until early spring.

One of the important points in growing pears is to gather them at the proper time. Summer and autumn pears should be gathered about ten days before they are ripe. Winter varieties can be left until the leaves begin to fall; if they will hang that long.

At the present time there is a strong demand for choice fruit and they should have the best kind of cultivation; the fruit should be thinned if there is danger of the tree over-producing. Care should be used in selecting for market only the best, and with such effort and system on the part of the grower, they will yield a satisfactory profit.

'I'he pear succeeds on most soils, but does best on a rather heavy loam or clay. Budded on its own stock it makes a standard tree, and on French or Anger's Quince, a dwarf, the former being the best adapted to large permanent orchards, the latter to yards and gardens.

\section{Standard Pears}

All Budded Trees on Whole Roots of Imported French Pear Seedlings Wholesale Price of Standard Pear Trees Except as Noted

\begin{tabular}{|c|c|c|c|c|c|c|}
\hline & & HEIGHT & CALIPER & EACH & IEN & HUHDRED \\
\hline $\begin{array}{l}\mathrm{XXX} \\
\mathbf{X X} \\
\mathbf{X} \\
\mathrm{Y} Y \mathrm{Y}\end{array}$ & $\begin{array}{llll}2 & \& & 3 & \text { Year } \\
2 & \& & 3 & \text { Year } \\
2 & \& & 3 & \text { Year } \\
1 & \text { Year }\end{array}$ & $\begin{array}{l}6 \text { to } 7 \mathrm{ft} . \\
5 \text { to } 6 \mathrm{ft} \text {. } \\
4 \text { to } 5 \mathrm{ft} \text {. } \\
3 \mathrm{ft} \text {. } ~ u p ~\end{array}$ & $\begin{array}{c}3 / 4 \text { \& up } \\
5 / 8 \text { to } 3 / 4 \\
1 / 2 \text { to } 5 / 8 \\
\text { Stocky Buds }\end{array}$ & $\begin{array}{l}.43 \\
.38 \\
.33 \\
.43\end{array}$ & $\begin{array}{r}\$ 3.80 \\
3.30 \\
2.80 \\
3.80\end{array}$ & $\begin{array}{r}\$ 30.00 \\
25.00 \\
20.00 \\
30.00\end{array}$ \\
\hline
\end{tabular}

Rate -1 to 5 at each rate, 5 to 25 at 10 rate, 25 and over at 100 rate.

\section{Summer Varieties}

Clapp's Favorite. Very large size; with crimson and russet. The flesh is white, fine grained, juicy, melting and of excellent quality. The tree is erect, hardy, healthy, vigorous and very productive. Blooms late and is not liable to be caught by late spring frosts. Adapted to all Pear growing sections. Ripens ten days before Bartlett.

Koonce. Large size for an early pear; golden yellow and bright red; very beautiful. Tree hardy்; seldom blights; produces good crops every year.

Wilder. Medium size; yellow with red cheek; fine quality ; ripens very early. Tree a vigorous grower and early bearer.

\section{Autumn Varieties} Bartlett. One of the oldest varieties, both for commercial orchards and home garden. Fruit large size, clear bright yellow, with blush on the sunny side, buttery, melting. and rich flavor. The one great pear for canning, shipping and home use. The tree is erect, vigorous, hardy and a late bloomer. Comes into bearing third year after planting. Season early Sept.

Beurre Bosc. Extra large size; deep russet yellow; high flavored and delicious. It is a favorite in the eastern markets where it brings the very highest price. Ripens in October and can be marketed at that time, but for best returns should be put in storage and marketed during the holiday season. Tree reasonably strong, but rather crooked grower in the nursery. In the orchard it is a good grower and very productive. Sold at each rate only.

Clairgeau (Beurre Clairgeau.) Very large size; light yellow shaded with crimson and russet. Flesh yellow, juicy, high flavored. Tree a medium grower and abundant bearer. October and November.

Comice. Large size; yellow, faintly blushed with crimson. Flesh rich, white, fine grained, juicy and aromatic. Comice is well recommended in the Eastern and Western pear growing districts; a long keeper, carries well, and a good market variety. The tree is vigorous. hardy and productive; bears about the fourth year; a very late bloomer. Season last of September to October first.

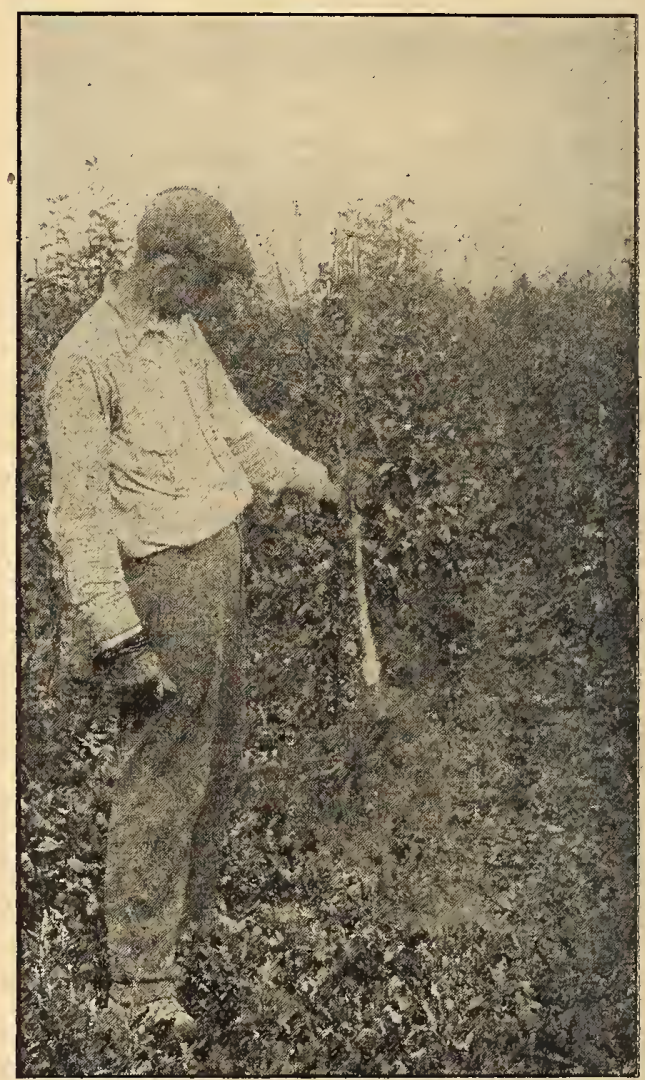

UP-LAND BARTLETT PEAR IN OUR NURSERY Showing a few rows. Block contains 25,000 trees. 


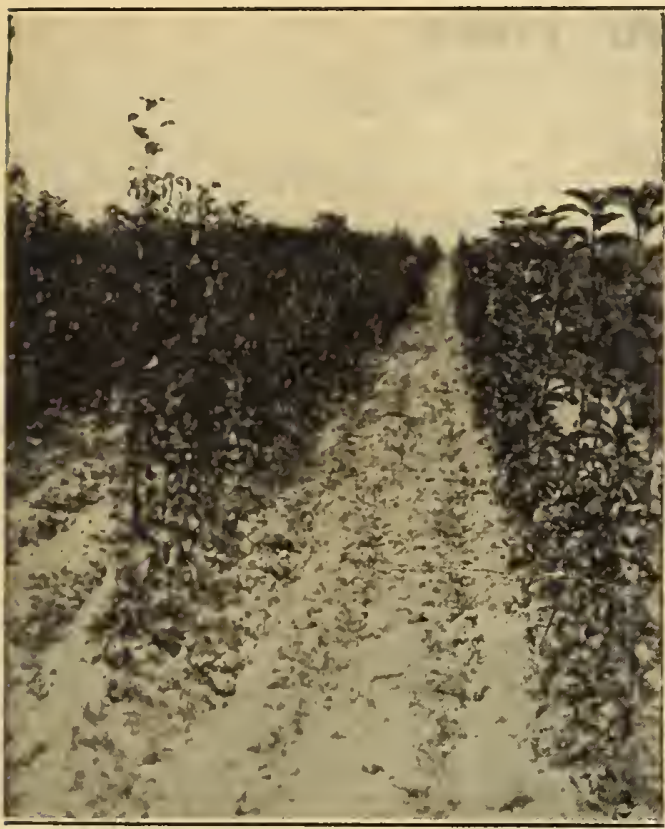

UP-LAND PEAR TREES ONE YEAR OLD Block Contains 30,000 Trees

Lincoln (Illinois Lincoln.) Very large size, clear yellow with bright red cheek on sunny side; rich, juicy, high quality. Good shipper and keeps well. Tree strong, vigorous, upright grower; hardy, productive; late bloomer; bears usually the fourth year. Is remarkably resistant to blight. Season about same as Bartlett.

Rossney. Medium to large size; pale yellow with crimson blush; flesh tender, sweet, juicy and high flavored. It is an excellent keeper and shipper. Tree a very strong grower; hardy in both wood and bud, and of attractive form. Season two weeks later than Bartlett.

Seckel. The richest, and highest flavored pear grown. Medium to small size; golden yellow, heavily russeted. The flesh is very fine grained, white, sweet, melting and juicy. It is productive to a fault and should be thinned in early summer. The tree is a short stocky grower in both nursery and orchard, and will stand rich ground and considerable forcing. Should be planted closer than other varieties. Blooms late. Bears about the fourth year. Oct.

Sheldon. Medium to large size; yellowish russet; flesh juicy and of a most delightful flavor. Tree erect, hardy, vigorous and productive. A good variety for home and market.
Duchess (Angouleme) Fruit very large, dull greenish yellow and russet; flesh white, rich and of good quality. A most dependable cropper and profitable market variety. Bears very young, usually the second year after planting. Valuable as both Standard and Dwarf. The largest planted and most profitable variety as dwarf. Oct. and Nov.

Flemish Beauty. Large, yellow, brownish red; flesh tender, juicy and high flavored. Tree very hardy, vigorous and fruitful. Sept. and Oct.

Worden Seckel. A seedling of Seckel with same quality and habits, except that it is large. size; of better appearance and a longer keeper. October.

Louise Bonne. Yellow with dark red cheek; good quality. Very successful as a dwarf; good commercial variety. Sept. and Oct.

\section{Winter Varieties}

Aniou (Beurre d' Anjou.) The best Anjou commercial pear of its season. Large, handsome greenish yellow, blushed dull red and russet; flesh white, fine grained, buttery, melting and a rich high flavor. One of the best shippers; always looks good and keeps well. The tree is an upright grower, very vigorous, hardy, long lived and productive. The exceptional qualities of the tree and fruit make this one of the most profitable commercial varieties for all pear growing sections. Ripens in October; keeps until mid-winter.

Lawrence. Sometimes called Winter Bartlett. Fruit medium to large size; yellow covered with brown dots; flesh whitish, buttery and rich. Tree a moderate grower and prolific bearer. An early winter pear that is well known and a general favorite.

Winter Nelis. Medium to large size; yellow and russet; flesh yelluw, fine grained, sweet and of the very highest quality when fully ripe. Tree is a straggling grower, very hardy and productive. On account of its excellent keeping and shipping qualities this is a valuable commercial variety.

Kieffer. Large size; yellow, with brilappearance but only fair in quality; flesh is juicy and coarse, but excellent for canning. Kieffer should be picked about the time the leaves begin to fall, and allowed to ripen in a cool dark place. The tree is an exceptionally strong grower, and a young and annual bearer its common fault is to over-bear, and needs thinning in early summer to obtain good sized fruit. Has become one of the most profitable commercial varieties on account of its good keeping and shipping qualities.

\section{ROSEMERE POULTRY AND FRUIT FARMS}

The Wm. J. Reilly Nurseries, Dansville, N. Y.

Eaton Rapids, Mich. Apr. 12, 1918

Dear Sirs :-Enclosed find order to be shipped at your earliest convenience. Also check covering same. Being assured of your high quality of stock makes us feel doubly safe in again ordering stock of you. Never saw a bunch of Nursery Stosk packed for shipment as nicely as our large order was prepared lastyear. On account of tieup on the railroad, the stock was over a month on the road. Out of a block of a hundred Winter Bananas, not one tree failed to live and make excellent growth. The root growth of your stock was remarkable. It is with pleasure that we recommend your stock to those who wish "quality first".

Yours very truly

A. N. Maguire 


\section{Dwarf Pear Trees}

The dwarf varieties require less than one-fifth the space necessary for the standard varieties, and though the tree is dwarf, the fruit is the same size as standard, and is borne in large quantities. It is valuable both for the home garden and orchard planting for commercial purposes. It is a good filler for apple or Standard Pear Orchards, because it is an early bearer and takes up but a small space. Trees should be planted ten feet apart. We can furnish the following varieties in Dwarf (for description see Standard varieties.) Wilder.

Duchess d'Angouleme, Anjou, Bartlett, Clapp's Favorite, Flemish, Louise Bonne, Seckel and

\section{Wholesale Price of Dwarf Pears}

All Budded Trees on Whole Roots of Imported French Angers Quince Stocks

\begin{tabular}{|c|c|c|c|c|c|c|}
\hline & & HEIGHI & CALIPER & EACH & TEN & HUNDRED \\
\hline $\begin{array}{l}\text { XXX } \\
\text { XX } \\
X\end{array}$ & $\begin{array}{l}2 \text { Year } \\
2 \text { Year } \\
2 \text { Year }\end{array}$ & $\begin{array}{l}4 \text { to } 5 \mathrm{ft} \text {. } \\
3 \text { to } 4 \mathrm{ft} \text {. } \\
2 \text { to } 3 \mathrm{ft} \text {. }\end{array}$ & $\begin{array}{l}5 / 8 \text { \& up } \\
1 / 2 \text { to } 5 / 8 \\
3 / 8 \text { to } 1 / 2\end{array}$ & $\begin{array}{l}.30 \\
.25 \\
.20\end{array}$ & $\begin{array}{r}\$ 2.50 \\
2.00 \\
1.50\end{array}$ & $\begin{array}{r}\$ 17.50 \\
12.50 \\
10.00\end{array}$ \\
\hline
\end{tabular}

Rate-1 to 5 at each rate, 5 to 25 at 10 rate, 25 and over at 100 rate.

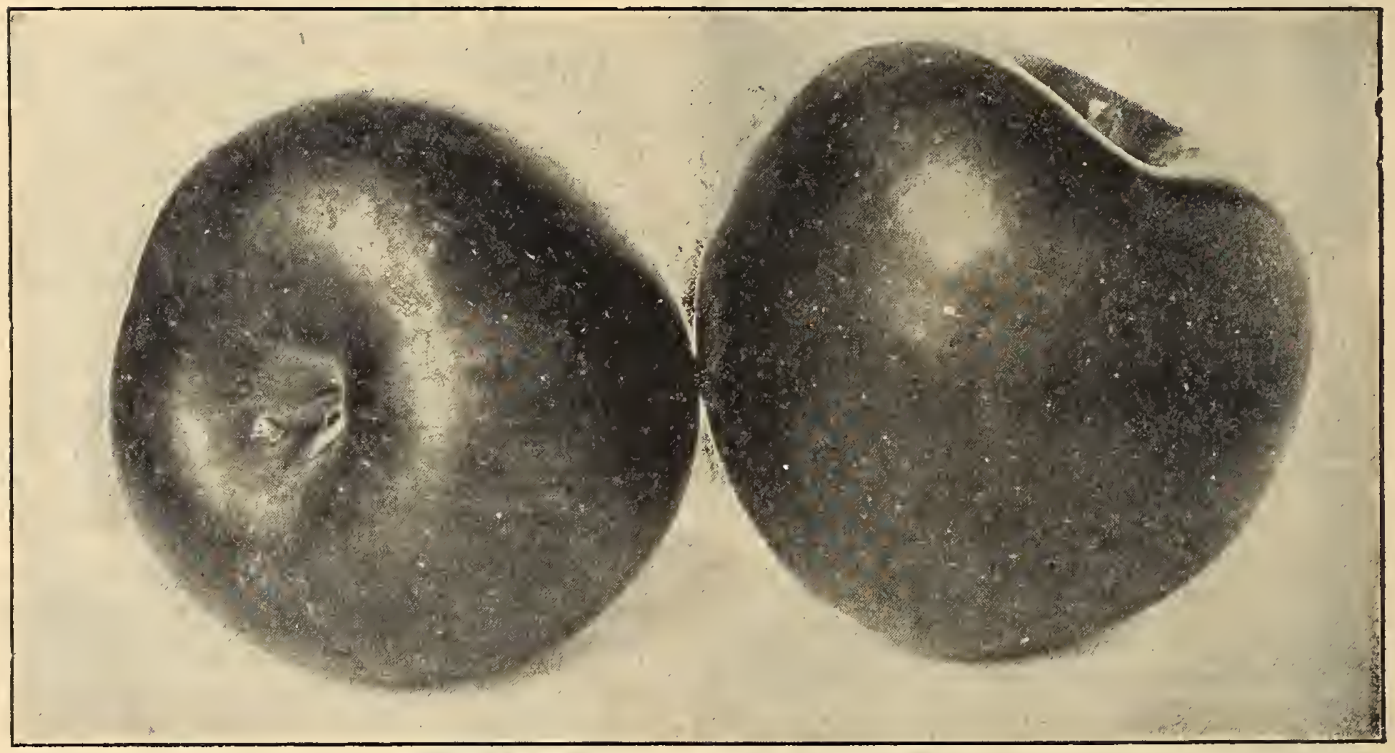

RED ASTRACHAN-A Popular Variety on Dwarf.

\section{Dwarf Apples}

Dwarf Apples are principally adapted to the garden. They do not take up as much room as standard trees and come into bearing earlier. We can supply the following varieties. For descriptions see standard varieties.

Duchess of Oldenburg, Baldwin, MeIntosh, Yellow Transparent, Red Astrachan, Wealthy, Winter Banana, Northern Spy and Delicious.

\section{Wholesale Price of Dwarf Apple Trees}

All Budded on Whole Roots of Imported English Paradise Stock

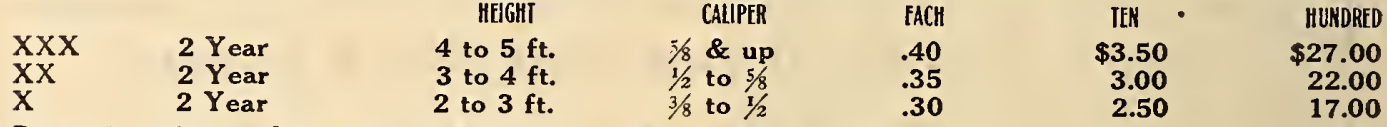

Rate -1 to 5 at each rate, 5 to 25 at 10 rate, 25 and over at 100 rate.

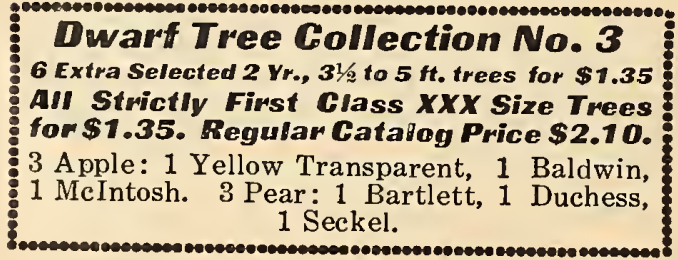

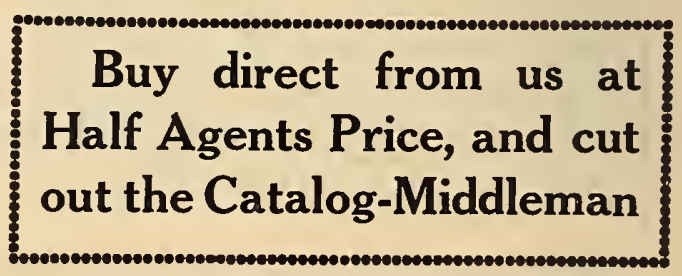




\section{Cherries}

\section{All Budded on Whole Roots of Imported French Mahaleb and Mazzard Stock}

The Cherry like the Peach do their very best on light soil, but will succeed in any soil that is dry. The Sweet varieties are of rapid growth with large, glossy leaves, forming fine pyramid shaped heads, and producing large crops of luscious sweet fruit. Sour varieties generally produce acid fruit, and do not attain so large size; are hardier and better adapted for shipping to market. We know of nothing in the fruit line that gives promise of better returns than a good well kept Cherry Orchard. There are very few markets that are ever well supplied with this fruit.

\section{Wholesale Price of All Varieties of Sour Cherry Trees}

\begin{tabular}{|c|c|c|c|c|c|c|}
\hline & & HEIGHT & CALIPER & $\mathrm{EACH}$ & IEN & HUNDRED \\
\hline $\begin{array}{l}X X X \\
X X \\
X \\
X X X\end{array}$ & $\begin{array}{l}2 \text { \& } 3 \text { Year } \\
2 \& 3 \text { Year } \\
2 \text { \& } 3 \text { Year } \\
1 \text { Year }\end{array}$ & $\begin{array}{l}6 \text { to } 7 \mathrm{ft} \text {. } \\
5 \text { to } 6 \mathrm{ft} \text {. } \\
4 \text { to } 5 \mathrm{ft} \text {. } \\
3 \mathrm{ft} . \& \mathrm{up}\end{array}$ & $\begin{array}{c}3.4 \text { \& up } \\
5 / 8 \text { to } 3 / 4 \\
1 / 2 \text { to } 5 / 8 \\
\text { Stocky Buds }\end{array}$ & $\begin{array}{l}.43 \\
.38 \\
.33 \\
.43\end{array}$ & $\begin{array}{r}\$ 3.80 \\
3.30 \\
2.80 \\
3.80\end{array}$ & $\begin{array}{r}\$ 30.00 \\
25.00 \\
20.00 \\
3000\end{array}$ \\
\hline
\end{tabular}

Rate- -1 to 5 at each rate, 5 to 25 at 10 rate, 25 and over at 100 rate.

\section{Large Montmorency This variety} extensively in all localities, and is the main commercial variety among the orchardists. It is the largest and most productive of the sour varieties. The fruit hangs on well after dead ripe, and does not crack or rot in even hot rainy weather. The flesh is tender but firm, making it a good shipper. The tree is the largest and strongest grower of the sour varieties; especially hardy and productive; very hardy in bloom and very seldom injured by late spring frosts, or severe winter weather. Commercial growers plant about one-half of their orchard to Montmorency, with Early Richmond to ripen before and English Morello to ripen after.

Early Richmond Best early variety Early Richmond for commercial planting, ripening ten days before Montmorency. Medium size, ruundish; color, bright light red. Flesh light colored, juicy and good quality; hangs well to the tree when ripe. Tree hardy, vigorous and very productive; long lived. Largely used for canning but not equal to Montmorency except where earliness is the principal consideration.

Montmorency Ordinaire. Fruit not as large as Large Montmorency. Popular in some sections on account of its heavy bearing qualities, and producing of the fruit in clusters, making picking easier and cheaper. Ripens just after Large Montmorency.

Dyehouse. Similar to Richmond and ripens just before it. A good early market variety. Medium sıze; red; acid; small pit; hardy and productive.

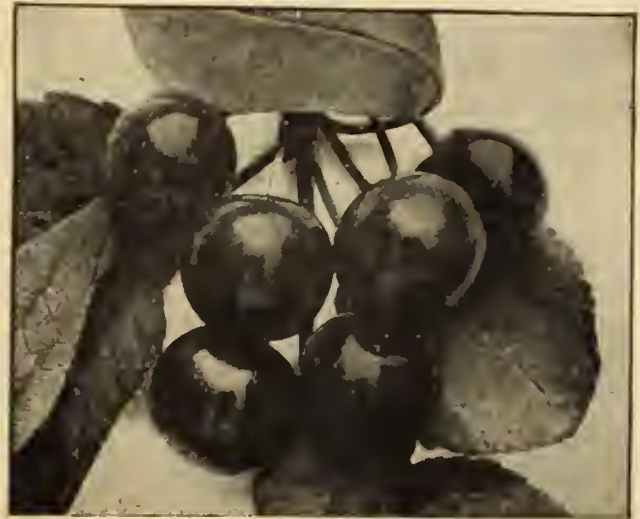

LARGE MONTMORENCY (Reduced)
English Morello Valuable as a late commercial vari ety, and on account of its early bearing habits. able fruit in the Nursery on two year trees, especially when grown on up-land. Fruit medium to large, dark red, becoming almost black when fully ripe. Flesh dark crimson, meaty, firm, rich acid, good for canning. Ripens twenty days after Montmorency and will hang on the tree a long time after fully ripe. Tree not as strong a grower as Montmorency, but one of the very hardiest, and best producers.

May Duke. This is one of the old popular garden varieties, and still one of the best for this purpose. Color bright red, to nearly black when fully ripe; flesh purplish red; juicy melting, rich and fine flavor. Tree vigorous resembling the sweet varieties, and about the same degree of hardiness.

Olivet. Large; skin dark red; tender, rich, vinous with mild subacid flavor. Tree strong grower and productive.

Ostheime. Large heart-shaped; almost black when fully ripe. Very hardy and recommended for cold climates.

Baldwin. Early, vigorous and hardy; rapidly coming into favor. Fruit large size almost round, dark transparent wine color; slightly acid, but sweet for a sour cherry.

Wragg Said to be an improved English Wrello; similar in fruit, but larger. This variety is extensively planted in some sections, especially in Colorado where it is of great commercial importance. Tree very hardy. long lived and heavy bearer.

\section{$\$ 797.50$ from less than One Acre of Cherries}

My 128 Montmorency Cherry Trees, 10 years old and occupying less than one acre of ground yielded me seven and one-fourth tons of cherries last year. They are planted $17 x / 2$ by 20 feet and are Mahaleb stockMr. Collamer in Western New York Horticutural Society.

At the same meeting Howard W. Clark, Rochester, N. Y., says "We paid $51 / 2 \varnothing$ per pound for Montmorency at the canning factory." 


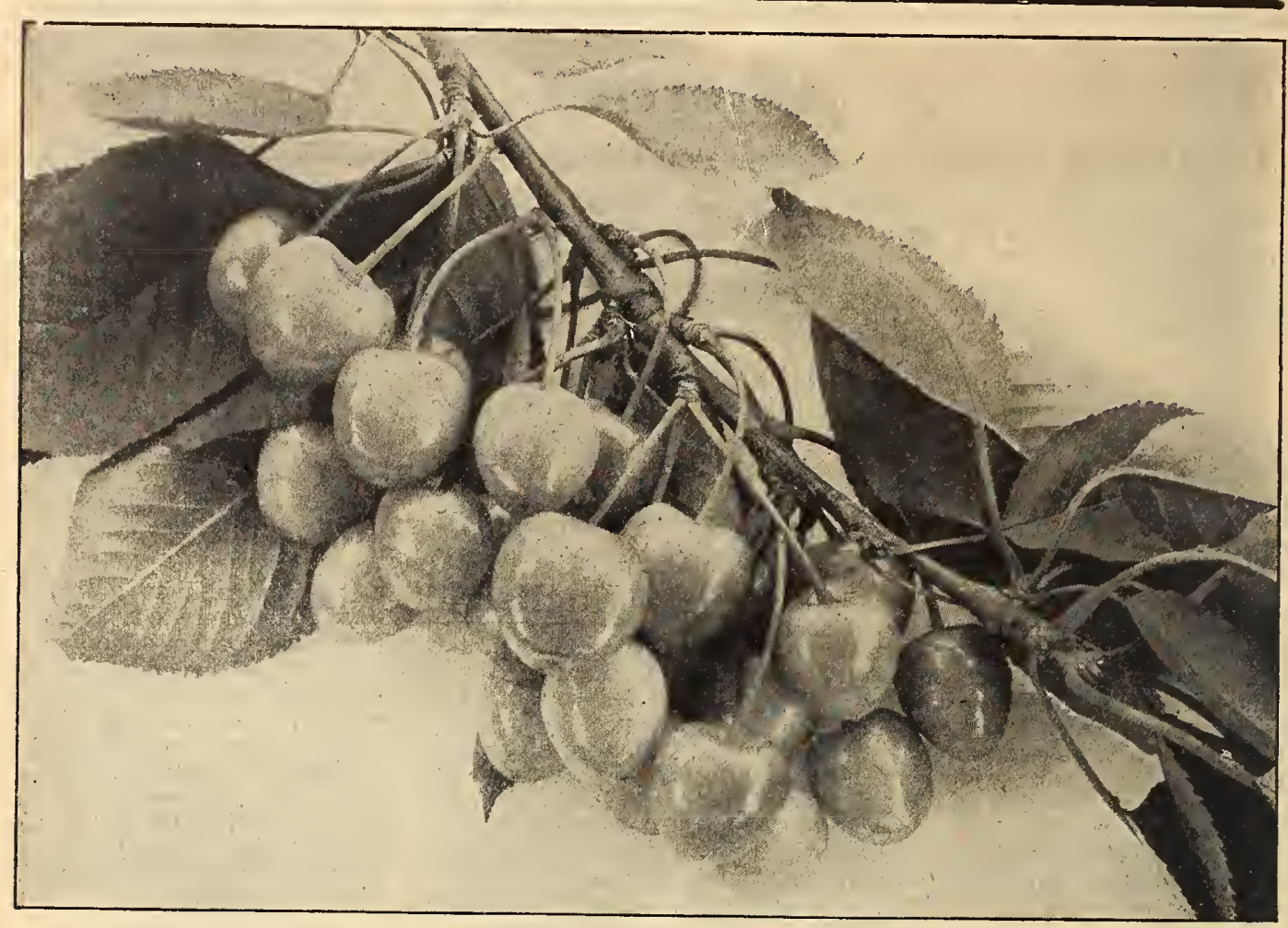

NAPOLEON THE BEST WHITE SWEET CHERRY

\section{Sweet Cherry Trees}

\section{Wholesale Price of All Varieties of Sweet Cherry Trees}

\begin{tabular}{|c|c|c|c|c|c|c|}
\hline & & HEIGHT & CALIPER & EACH & IEN & HUNDRED \\
\hline $\begin{array}{l}X X X \\
X X \\
X \\
X X X\end{array}$ & $\begin{array}{l}2 \text { \& } 3 \text { Year } \\
2 \text { \& } 3 \text { Year } \\
2 \text { \& } 3 \text { Year } \\
1 \text { Year }\end{array}$ & $\begin{array}{l}6 \text { to } 7 \mathrm{ft} \text {. } \\
5 \text { to } 6 \mathrm{ft} \text {. } \\
4 \text { to } 5 \mathrm{ft} \text {. } \\
3 \mathrm{ft} \text { \& } \mathrm{up}\end{array}$ & $\begin{array}{c}3 / 4 \text { \& up } \\
5 / 3 \text { to } 3 / 4 \\
1 / 2 \text { to } 5 / 8 \\
\text { Stocky Buds }\end{array}$ & $\begin{array}{l}.43 \\
.38 \\
.33 \\
.43\end{array}$ & $\begin{array}{r}\$ 3.80 \\
3.30 \\
2.80 \\
3.80\end{array}$ & $\begin{array}{r}\$ 30.00 \\
25.00 \\
20.00 \\
30.00\end{array}$ \\
\hline
\end{tabular}

Rate- to 5 at each rate, 5 to 25 at 10 rate, 25 and over at 100 rate.

Black Tartarian The standard dark sweet variety for central and eastern sections, for both market and home use. Large size, nearly black, heartshaped. Tender, juicy, sweet of fine quality. Tree an upright, dense grower, remarkably vigorous, and a regular bearer of large crops. We recommend it as the best all around sweet cherry.

Bing One of the largest black sweet Bing cherries. Flesh juicy but firm; a good shipper. Tree a vigorous upright grower, and productive. Not as hardy as Black Tartarian. Originated in Oregon and is extensively planted in the Pacific Northwest where it is considered one of the most profitable. Where planted in the central and eastern sections, it is gaining in favor, and seems to succeed better than some of the old varieties.

Lambert Another variety from Oregon; of later introduction than Bing. We do not think it has been sufficiently tried out to recommend it for large commercial plantings in the Central or Eastern sections. One of the largest sweet cherries and one of the best in quality; dark red, turning almost jet black when ripe. Flesh firm, meaty, rich. Tree rugged, a strong grower, and a young and heavy bearer.
- Windsor. Originated in Canada and is one of the hardiest of the sweet sorts. Fruit large size; liver colored; flesh remarkably firm and of fine quality; exceedingly valuable as a late commercial variety. Tree an upright, vigorous and rapid grower.

Schmidt's Bigarreau. A good late commercial variety for planting in the eastern states and Canada. Fruit large, often measuring an inch in diameter. Color dark purple to nearly black; flesh dark red, very firm; sweet, rich and of good quality. The tree is large, vigorous, spreading in habit and very productive.

Napoleon (Royal Ann.) The best qualNapoleor ity and most profitable yellow sweet cherry. An attractive yellow with bright red cheek. Large size, sweet, heart-shaped. Flesh very firm, juicy and delicious. Tree a vigorous upright grower and bears heavy crops. We highly recommend Napoleon for commercial planting, and for home use.

Governor Wood. Large, heart-shaped; light yellow and red; juicy sweet and rich. An old variety that is still a favorite in many sections. Tree a strong grower, with more of a spreading head than most other varieties.

Yellow Spanish. Fruit large, yellow and bright red; juicy, rich and high flavored. Tree 


\section{Plums}

\section{All Budded Trees on Whole Roots of Imported French Myrobolan Plum Seedlings}

The Plum, like the pear and other fine fruits attains its greatest perfection on our heavy soil, but will succeed on almost any soil that is made rich. The Plum is entirely free from disease. The curculio, a small dark brown beetle, often stings the fruit, causing it to drop off; by observing the following directions you will get a good crop of fine fruit. As soon as the blossoms have fallen, give the tree a sudden jar by striking a smart blow with a hammer on the stub of a limb sawed off for that purpose; this should be done in the morning while the dew is on. There are so many careless or indifferent growers who do not take these precautions, that the man who does will not only have a good supply of the best fruit, but will have a monopoly of the market.

\section{Wholesale Prices of All Varieties of Plum and Prune Trees}

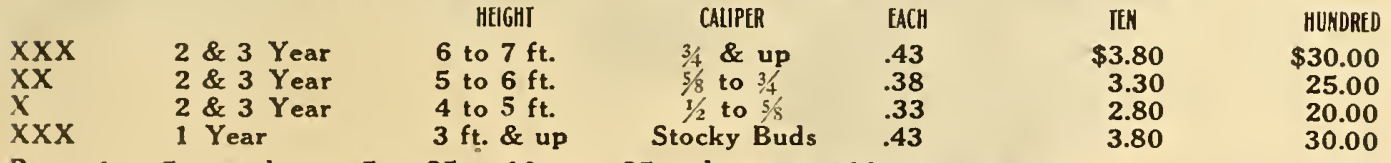

Rate -1 to 5 at each rate, 5 to 25 at 10 rate, 25 and over at 100 rate.

\section{Japan Plums}

Abundance Fruit large and beautiful; Abundarce amber turning to bright cherry red; flseh yellow, tender, juicy, rich. Vigorous and productive. Valuable for market. Aug.

Burbank Very large; clear cherry red; with a very agreeable flavor. Bears young and abundantly. Good keeping and shipping qualities. Excellent commercial sort. August, later than Abundance.

Climax. Very large; deep rich red; fine flavor. One of the earliest to ripen.

Hale. Large; bright orange; mottled with cherry red; superb quality. Sept.

Octobe: Purple. Large, round; reddish purple: good quality. A strong growing tree, bearing immense crops. Very valuable market sort. First of October.

Red June Medium to large; deep verflesh light lemon yellow, firm, delightful. The best early market sort. We recommend it for commercial orchard planting. Last of July.

Satsuma. Large; reddish purple; quality fine, delicious for canning. September.

Sultan. Large; deep wine red. Its size and handsome appearance render it a valuable market sort. Early Aug.

Siniro. Medium size. yellow, and very sweet. The best quality of any of the Japan plums. We have fruited it in Nursery row and can recommend it highly for garden planting. Sept.

Wickson. Very large; deep red with white bloom; flesh firm, sugary, delicious. Remarkably long keeping qualities and an excellent commercial sort. Sept.

Maynard. One of Luther Burbank's latest introductions and said to be the nearest perfect of this class of plums. A strong and very rapid grower, fruits heavily every year, bearing its burden of fruit on the inside of the tree. Fruit is very large, nearly round, color deep, dull red, with thin whitish bloom. Flesh firm, melting and juicy, rich and sweet, extra fine quality. Its shipping qualities are unsurpassed. Follows Climax in ripening.

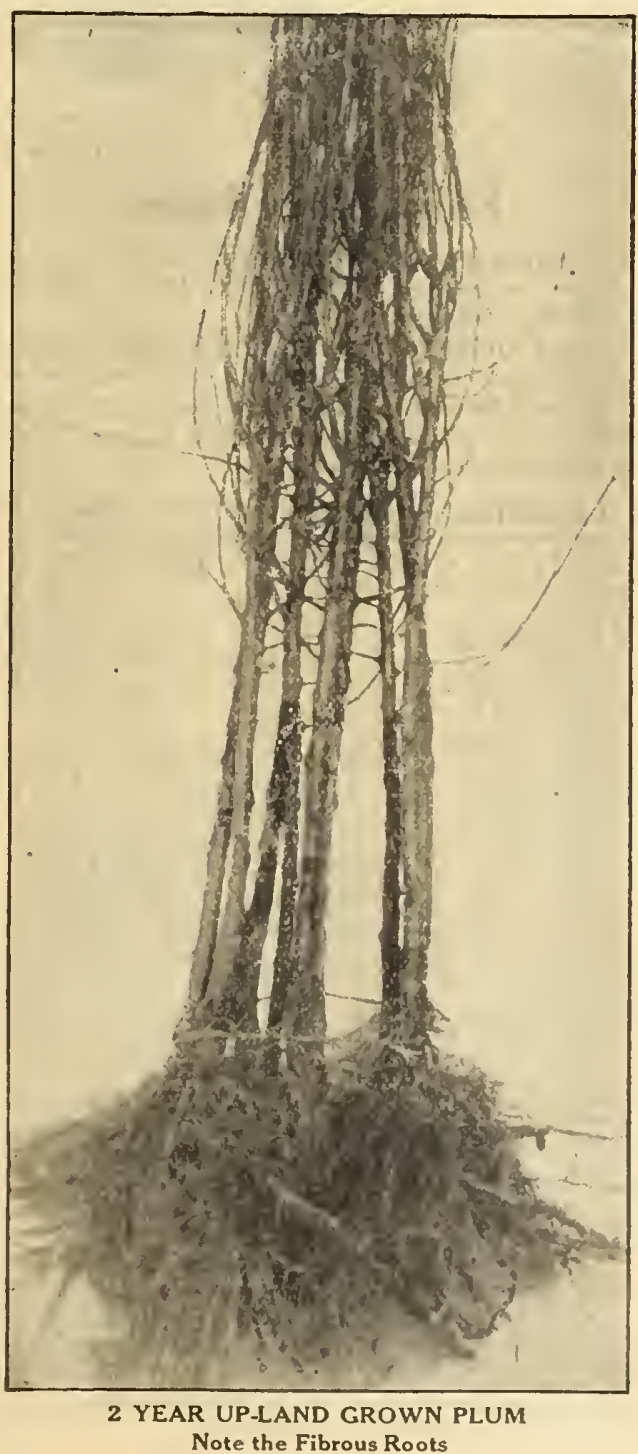




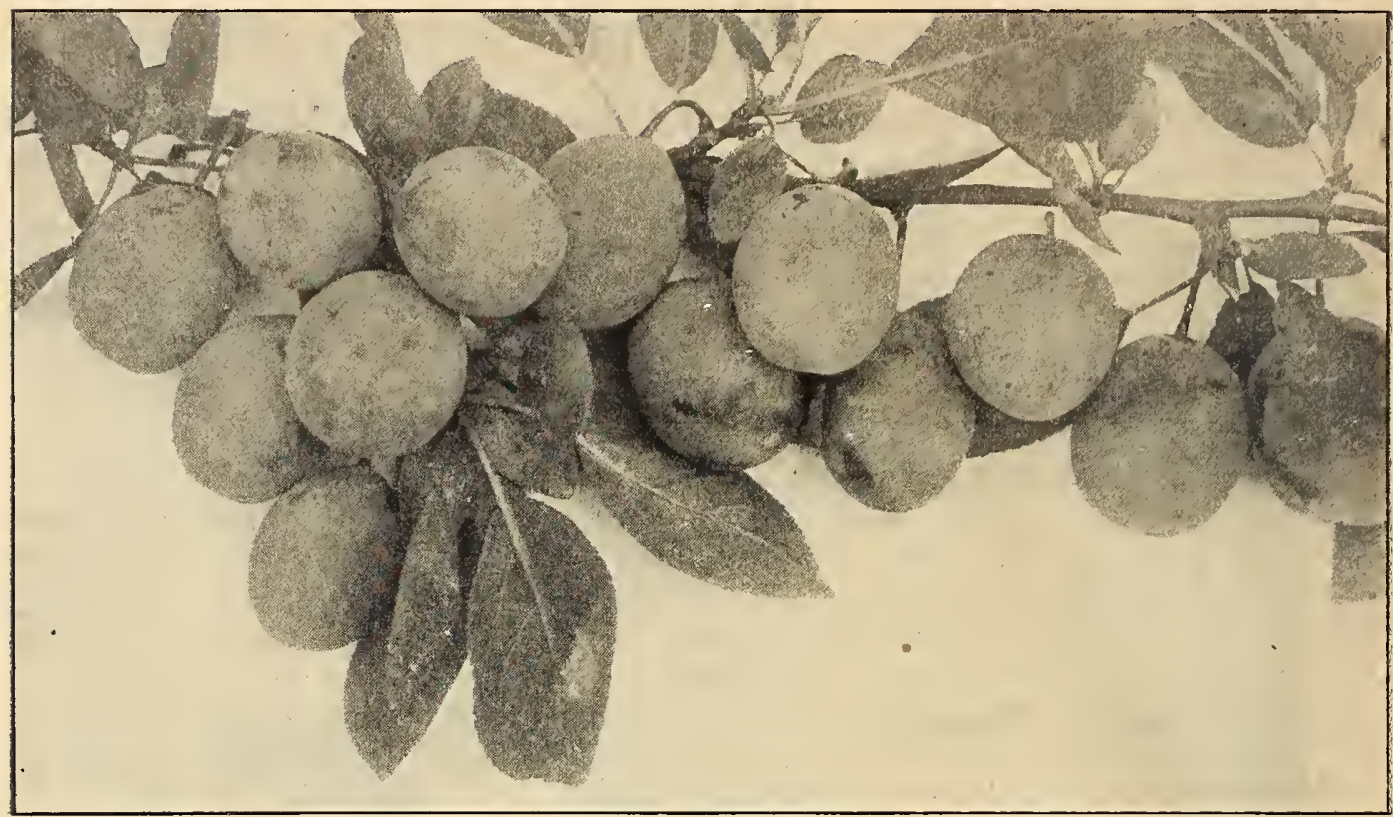

\section{SHROP DAMSON PLUM}

\section{European Plums}

Bradshaw Large; dark red,flesh green, market. August.

Coe's Golden Drop. Large; light yellow, flesh firm, rich and sweet. Last of September.

French Damson. Medium size; dark copper color. Very hardy and an annual bearer. Tree a light grower. October.

German Prune A large, long, oval teemed for drying; color dark purple, of very agreeable flavor. September.

Fellemburg (Italian Prune) A fine flesh juicy and delicious; very free stone. Good commercial sort. September.

Grand Duke. Large; violet red, fine quality, free from rot, very productive. Tree a moderate grower. Last of September.

Imperial Gage. Large; pale green, juicy, sweet, rich, and excellent. Middle of August.

York State Prune Large; blue, Best prune for market or garden. This prune originated here at Dansville as a seedling from German Prune and has been sold to fruit buyers for that variety in large quantities at profitable prices. Tree a vigorous grower and good bearer.

Monarch. Tree robust, dense foliage, an abundant bearer. Fruit very large, roundish, oval, dark purplish hlue, perfect freestone. Good for market. Last of Sept.

Wm. J. Reilly, Dear Sir:-I have received my order of trees in perfectly good condition. Am well pleased
with your strong rooted, healthy trees, and your honest dealings which give perfect satisfaction. The Peach trees which I received from your nursery two years ago are bearing and True to Name. We headed them back severely after planting, and they have made a growth of 8 feet high and 9 feet wide. This is proof of the High Quality of Stock you grow. Several of my neighbors after comparing their trees with mine are sending you their orders, and I will continue to recommend your stock and Honest Dealings.
Lombard Medium, violet red, juicy, the leading market variety. August.

Moore's Arctic. Small, purplish black, juicy, sweet, immense bearer; one of the hardiest in bud and bloom. September.

Niagara This plum has become exceedNew York, where it originated. It is a very early plum, and valuable for this reason. It is red, large size, making an attractive appearance in market, and possesses good shipping qualities. It bears enormous crors of fruit with great regularity. The tree is an upright grower, vigorous and healthy.

Shipper's Pride. Large, dark purple; very showy, often measuring two inches in diameter: fine, juicy and sweet. September.

Geuil. Fruit very large, deep bluish purple, covered with a thick bloom; flesh yellowish green, coarse, sweet and pleasant; great bearer and very early. Tree a hardy and rapid grower. September.

Reine Claude (Bavay's Green Gage.) liable to rot. Good bearer and valuable for commercial orchards. September.

Shropshire Damson Large; amber and sprightly; productive and not liable to rot. Good commercial sort. September.

Yellow Egg. Large and beautiful; productive, egg shaped, yellow. Flesh coarse, but good for cooking. August. yellow; juicy, excellent and of fine quality. Not

Palmyra, $\mathrm{Pa}$ Very truly yours, 


\section{Bearing Age Trees}

We Recommend These to the Planter and Know That They Will Give Perfect Satisfaction

$B$ EARING AGE TREES during the past few years have proven of exceptional value both in the commercial and home orchard. These are four and five years old (except as noted) and were root pruned at 2 years by cutting under with the digger, they have a fine fibrous root system, and will live and grow as well as younger trees on this account.

Bearing age trees require very little trimming either root or top, simply remove any branches that are not required, and prune roots so they will go in a hole a foot across and 15 inches deep.

Some of the early bearing varieties have already born fruit in the nursery row, and should bear some fruit the second year after planting. If they blossom the first year they should be picked off, as the fruit would not fully mature, and would. take vitality from the tree that it should have for limb growth.

\section{STANDARD APPLES}

$\begin{array}{llllcccc}\text { Bearing Age } & 4 \text { and } 5 \text { Years } & 7-8 \mathrm{ft} . & 1 \text { to } 1 / 2 \text { inch } & .60 & \$ 5.00 & \$ 100 & \end{array}$

VARieties: Baldwin, Duchess, Wealthy, Banana, Rome Bty., Staymans, York Imp., Northern Spy, Ben Davis, Stark, Talman Sweet, Grimes, N. W. Greening, R. I. Greening, McIntosh.

\section{StANDARD PEARS}

Bearing Age 4 to 5 Years 7 to $8 \mathrm{ft}$. 1 to $1 \mathrm{r} / 2$ inch $\quad \begin{array}{ccccc}10 & 100 & \$ 5.00 & \$ 35.00\end{array}$

VARieties: Bartlett, Clapp's Favorite, Anjou, Duchess, Seckel, Flemish, Kieffer.

\section{CHERRIES}

Bearing Age

4 to 5 Years 7 to $8 \mathrm{ft}$.

1 to $1 \frac{1}{2}$ inch

Each

.60

10
$\$ 5.00$

100

VARIETIEs: Black Tartarian, Napoleon, Windsor, Ea. Richmond, Morello, Montmorency.

\section{plums}

Bearing Age

4 to 5 Years 7 to $8 \mathrm{ft}$.

1 to $1 \frac{1}{2}$ inch

Each

10

$\$ 5.00$

100

VARIETIES: Abundance, Burbank, Red June, Satsuma, Lombard, York State Prune Shro Damson, Bradshaw, Shippers Pride, Reine Claude, Monarch, Yellow Egg, Geuii.

\section{PEACHES}

Bearing Age

2 to 3 Years $\quad 7$ to $8 \mathrm{ft}$. $\quad 7 / 8$ to 1 inch

Each

.60

VARIETIES: Elberta, Ea. Crawford, Late Crawford, Champion.

\section{DWARF PEARS}

Bearing Age 4 and 5 Years 6 to $7 \mathrm{ft}$. 1 to $1 / 2$ inch $\begin{array}{ccc}\text { Each } & 10 & 100 \\ .60 & \$ 5.00 & \$ 35.00\end{array}$

VArieties: Duchess, Anjou, Bartlett.

\section{DWARF APPLES}

Bearing Age 4 and 5 Years 6 to $7 \mathrm{ft}$. $7 / 8$ to 1 inch $\begin{array}{ccc}\text { Each } & 10 & 100 \\ 60 & \$ 5.00 & \$ 30.00\end{array}$

Varieties: Delicious, McIntosh, Banana, Fameuse, Gravenstein, Duchess, Yellow Transparent. Red Astrachan, Baldwin, Wealthy.

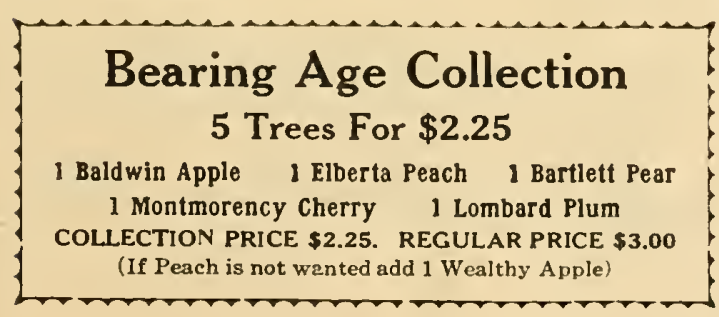

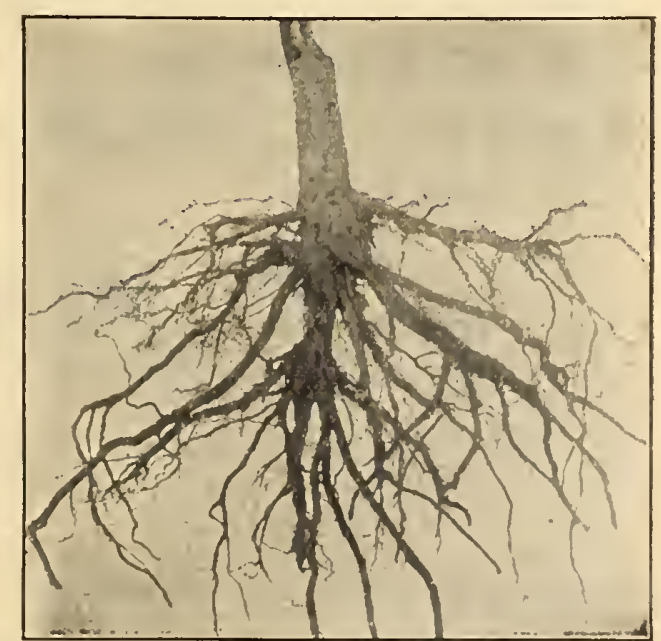

Root-Pruned Root System on Our Bearing Age Trees Makes Transplenting Easy 


\section{Quinces}

The Quince is attracting attention as a market fruit. The tree is hardy and compact in growth, requires but little space, is productive, giving regular annual crops, and comes early into bearing. The fruit is much sought after for canning for winter use. When put in the proportion of one quart of quinces to four of other fruits it imparts to them a most delicious flavor.

Wholesale Price of All Varieties of Quince Trees

\begin{tabular}{|c|c|c|c|c|c|c|}
\hline & & HEIGHT & CALIPER & EACH & IEN & HUNDRED \\
\hline $\begin{array}{l}X X X \\
X X \\
X \\
X X X\end{array}$ & $\begin{array}{l}2 \text { Year } \\
2 \text { Year } \\
2 \text { Year } \\
1 \text { Year }\end{array}$ & $\begin{array}{l}4 \text { to } 6 \mathrm{ft} \text {. } \\
3 \text { to } 4 \mathrm{ft} \text {. } \\
2 \text { to } 3 \mathrm{ft} \text {. } \\
3 \mathrm{ft} . \& \text { up }\end{array}$ & $\begin{array}{c}5 / 8 \text { \& up } \\
1 / 2 \text { to } 5 / 8 \\
3 / 8 \text { to } 1 / 2 \\
\text { Stocky Buds }\end{array}$ & $\begin{array}{l}.43 \\
.38 \\
.33 \\
.38\end{array}$ & $\begin{array}{r}\$ 3.80 \\
3.30 \\
2.80 \\
3.30\end{array}$ & $\begin{array}{r}\$ 30.00 \\
25.00 \\
20.00 \\
30.00\end{array}$ \\
\hline
\end{tabular}

Rate- -1 to 5 at each rate, 5 to 25 at 10 rate, 25 and over at 100 rate.

Orange. Fruit large, bright yellow, of - excellent flavor. A vigorous grower and an immense producer.

Meech. Fruit large, pear shaped, orange yellow; good quality.

Champion. A prolific and constant bearer, fruit averaging larger than the orange, more oval in shape, quality extra fine and a long keeper; bears very young. Ripens late.
Bourgeat. Tree a remarkable strong grower, surpassing all others, yielding immense crops; fruit of large size, round, rich, golden color; very tender when cooked; will keep until February in good condition.

Rea's Mammoth. A seedling of the orange, averaging much larger, of the same form and color.

\section{Apricots}

Beautiful and delicious fruit. In quality and appearance is between plum and peach, combining qualities of both. Ripening early, together with its delightful flavor makes it one of the most valuable fruits. Tree hardy as the peach. Requires about the same cultivation as the peach or plum. It ships well and commands a good price in any market. For drying and canning, it has no superior. The Russian varieties are quite distinct from the other European sorts; much hardier, earlier bearers and productive.

\begin{tabular}{|c|c|c|}
\hline $\operatorname{ces} 0$ & arieti & ico \\
\hline HEIGHT & CALIPER & EACH \\
\hline $\begin{array}{l}4 \text { to } 5 \mathrm{ft} \text {. } \\
3 \text { to } 4 \mathrm{ft} \\
2 \text { to } 3 \mathrm{ft} \text {. }\end{array}$ & $\begin{array}{l}\frac{5 / 8}{2} \& \text { up } \\
1 / 2 \text { to } 5 / 8 \\
3 / 8 \text { to } 1 / 2\end{array}$ & $\begin{array}{l}.43 \\
.38 \\
.33\end{array}$ \\
\hline
\end{tabular}

$\begin{array}{cr}\text { IEN } & \text { HUHDRED } \\ \$ 3.80 & \$ 27.00 \\ 3.30 & 22.00 \\ 2.80 & 17.00\end{array}$

$\begin{array}{ll}\mathrm{XX} & \mathbf{2} \text { Year } \\ \mathrm{XX} & 2 \text { Year }\end{array}$

$3 / 8$ to $1 / 2$

.33

Rate -1 to 5 at each rate, 5 to 25 at 10 rate, 25 and over at 100 rate.

\section{English Varieties} Harris. A hardy English sort, that is size; oblong orange; good quality; very early. The best variety for Eastern culture.

Moorpark. One of the largest. Yellow and very productive. An old and dependable variety. August.

\section{Russian Varieties}

Alexander. Fruit yellow, Hecked with red. Prolific. July.

Alexis. Yellow with red cheek, slightly acid but good. July.

Budd. Fruit white with red cheek. An im mense bearer. Best late variety. August.

Gibb. Medium, yellow sub-acid. The best early variety. Last of June.

\section{Mulberries}

The Mulberry is a very ornamental tree in garden or lawn. It is especially valuable in poultry yards, as the fruit drops when ripe through a long season.

New American. Tree a hardy and vigorous grower; the best quality for fruit; ripe from middle of June to middle of Sept. 4 to 5 feet. $50 \mathrm{c}$ each. 10 for $\$ 4.50$.

Russian. Very hardy, vigorous grower; valuable for feeding silk worms. Fruit of small size. $30 \mathrm{c}$ each. $\$ 2.50$ per 10 .

Downing. Fruit very large, black, handsome, sweet, rich and excellent. Same price as New American.
Lancaster, Pa., Nov. 26, 1917

The Wm. J. Reilly Nurseries, Dansville, N. Y.

Dear Sirs:-I received the trees in fine condition, and I am certainly well pleased with them. They are the cleanest and healthiest looking lot of stock I have ever received from any nursery.

Yours truly, Aaron R. Witmer. 


\section{Bargains in Small Sized Fruit Trees}

These little trees are well rooted, have straight trunks and few branches. If handled right they will make good trees and bear good fruit.

These trees are tied 10 in a bundle. We positively will not break bundles. Do not order less than 10 of a variety.

You should get your order in early as we have only a limited quantity of these little trees.

APPLE-2 Year, 3 to 4 Feet, $3 / 8$ to $1 / 2, \$ 2.50$ per $10, \$ 12.00$ per 100

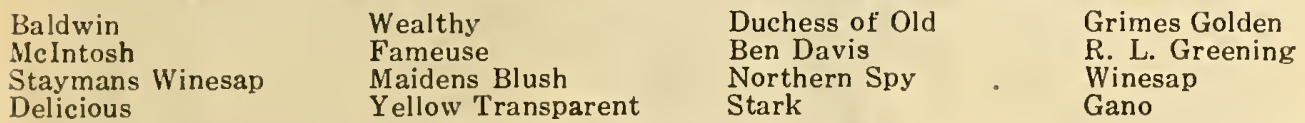

CHERRY-Sweet \& Sour, 2 Year, 3 to 4 Feet, $3 / 8$ to $1 / 2, \$ 2.50$ per $10, \$ 12.00$ per 100

$\begin{array}{llll}\text { Large Montmorency } & \text { Early Richmond } & \text { English Morello } & \text { Wragg } \\ \text { May Duke } & \text { Dyehouse } & \text { Bing } & \text { Lambert } \\ \text { Black Tartarian } & \text { Napoleon } & \text { Schmidts } & \text { Windsor }\end{array}$

Black Tartarian $\quad$ Napoleon $\quad$ Schmidts Windsor

Governor Wood

STANDARO PEAR-2 Year, 3 to 4 Feet, $3 / 8$ to $1 / 2, \$ 2.50$ per $10, \$ 12.00$ per 100

Bartlett

Flemish Beauty

Clapps Favorite

Anjou

Duchess

Sheldon

DWARF PEAR-2 Year, 2 to 3 Feet, $3 / 8$ to $1 / 2, \$ 1.50$ per $10, \$ 10.00$ per 100

Duchess d' Ang.

Louise Bonne

Bartlett

Anjou

Wilder

Seckel

Flemish Beauty

PEACH-1 Year, 2 to 3 Feet, $3 / 16$ to $5 / 16, \$ 1.50$ per $10, \$ 10.00$ per 100

Early Crawford

Champion

Beers Smock
Elberta

Belle of Georgia

Greensboro
Late Crawford

Niagara

Fitzgerald
Carman

Chairs Choice

Salway

\section{SHADELAND FRUIT FARM}

Mr. W. J. Reilly, Dansville, N. Y.

Martinsville Ind.

My Dear Sir:-Box of trees arrived in fine condition. They were on the road three weeks, but being so well packed they were nice and fresh and besides were fully up to grade in every way. Also wish to thank you for extras included.

Will remember you when needing anything in your line. Very truly yours,

Elmore Burkett.

The Wm. J. Reilly Nurseries, Dansville, N. Y.

Ballston Spa, N. Y.

Gentlemen:-Was just talking with a neighbor who bought sixteen Fruit Trees from C-four of them are living. Of the eighty I received from your nurseries all are doing fine with exception of five; two of these started and are making a little growth, the other three clid not start. I am well pleased with results from your stock.

Respectfully yours,

Louis Dubuque.

The Wm. J. Reilly Nurseries, Dansville, N. Y.

Richardson Park, Del.

Gentlemen:- The nursery stock arrived in the best of condition. Never saw such fine Pear and

Apple trees. They are all planted and look fine.

Yours with thanks,

A. K. Taylor.

Wm. J. Reilly Nurseries, Dansville, N. Y.

Torrington, Conn.

Dear Sir:-Please find enclosed order for $\$ 23.56$ worth of your trees. We have several hundred trees on our farm that were bought from you several years ago, and they are doing fine; all 0 . K. . grew well and are yielding enormous crops, especially in 1917 we had a bumper crop of fruit that brought good prices.

W. J. Casson.

The Wm. J. Reilly Nurseries, Dansville, N. Y.

Conestoga, Pa.

Gentlemen:-Enclosed find order for myself and a few of my neighbors. The trees that I bought from you several years ago are bearing, and they are doing well. I had Peaches last season that could not be beaten by any one. I remain,

Yours for success,

Grant H. Gardner.

Wm. J. Reilly Nurseries, Dansville, N. Y.

Albion, N. Y.

Gentlemen:-My trees were received this spring in fine condition; they are all growing and are the finest lot of trees I have ever seen. I shall need more next spring and will certainly get them from you. Yours truly.

Robert Sherbert. 


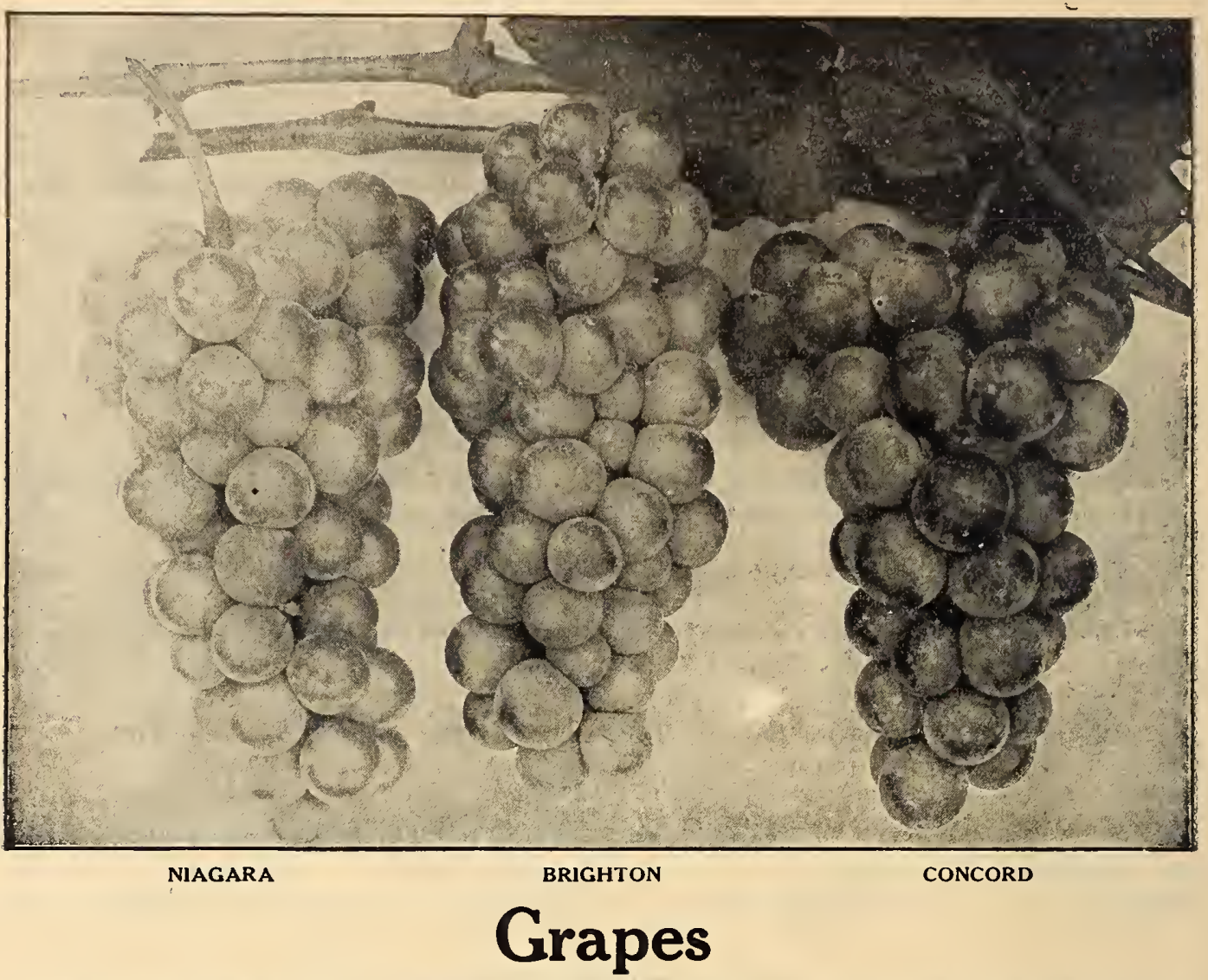

The vine comes quickly into bearing, yielding fruit usually the second year after planting; requires but little space, and when properly trained is an ornament to the yard, garden or vineyard.

The soil for the Grape should be dry. When not naturally so, it should be thoroughly drained. For maximum crops it should be deeply worked and well manured, always bearing in mind that it is essential to have them in a warm, sunny exposure.

\section{Prices of Grapes-Except as Noted}

$\begin{array}{lrrr} & \text { EACH } & \text { IEN } & \text { HUNDRED } \\ 2 \text { Year No. } 1 & 17 & \$ 1.25 & \$ 9.00\end{array}$

Parcel Post-Grapes can be sent by Parcel Post Prepaid for 2 c extra each

\section{Black Grapes}

Campbell's Early. A fine new very early. Clusters large and handsome. Berries large, black, with light purple bloom. Vine vigorous and a strong grower. $20 \mathrm{c}$ each. $\$ 1.50$ per $10, \$ 10.00$ per 100 .

Concord. A large, handsome, early grapes are grown; one of the old standard market varieties.

Hartford. Fair quality; very early; hardy; and a heavy annual bearer.

Eaton. Bunch large, compact. Berries very large, nearly black with blue bloom. Skin thick; good quality. 20c each. $\$ 1.50$ per 10 . $\$ 10.00$ per 100 .

Moore's Early. Bunch large, berry heavy bloom, vine exceedingly hardy. A very desirable early market variety.

Worden. A splendid grape of the Concord type; larger, better quality and earlier. Vine vigorous, hardy and productive.
Wilder (Roger's No. 4.) Bunch and berry very large; guod quality; juicy and sweet. Ripens with Concord.

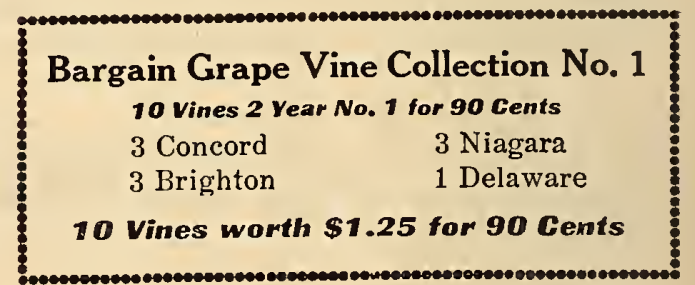

Elmira, N. Y., Nov. 23, 1917

Mr. Wm. J. Reilly, Dansville, N. Y.

Dear Sir:-Trees received and set out; all are in fine condittion. I am very much pleased with them, they are certainly a fine lot. I am sure they will all live. Thanking you for same, I am sincerely,
Mrs. Jane T. BurT 


\section{Red or Amber Grapes}

Agawam (Roger's No. 15.) Berries very large, with thick skin: pulp soft, sweet and sprightly; vigorous grower, ripens early.

Catawba. Berries large, round; when fully ripe of a dark copper color, with sweet, rich, musky flavor. Requires a long season to arrive at full maturity.

Delaware. Bunches small, compact; berries rather small, round; skin thin, light red; flesh very juicy, sweet, spicy and delicious.

Wyoming. Vine very hardy, healthy and robust, with leathery foliage; color similar to Delaware, and in size nearly double; flesh tender, juicy, sweet, with a strong native aroma. Ripens before Delaware.

Salem (Roger's No. 53.) A strong vigorous vine; berries large coppery red, thin skin, sweet and sprightly.

Woodruff. A handsome profitable market sort: vine vigorous, iron-clad constitution. Bunch and berry large, attractive; ripens early, fair quality, long keeper, good shipper. 20c each. $\$ 1.50$ per 10 . $\$ 10.00$ per 100 .
Brighton. Red. Bunch medium to large, long compact, should. ered; berries medium; skin thin; flesh tender, sweet, with scarcely any pulp; quality best. A free grower and very productive.

\section{White Grapes}

Niagara. Bunch medium to large; berry Niagara. large; skin thin and tough; color pale yellow when fully ripe. It is tender. sweet and good. Best of the white varieties. Ripens with the Concord.

Diamond. Vine vigorous and productive: bunch large, compact; berry medium size, greenish white with yellow tinge when fully ripe; best early white.

Green Mountain. Vine strong, vigorous and healthy: very hardy and productive, bunch and berry medium size; color greenish white; skin thin; pulp tender and sweet. $20 \mathrm{c}$ each. $\$ 1.50$ per 10. $\$ 10.00$ per 100 .

Pocklington. Bunch and berries large; a light golden yellow when fully ripe, juicy, tender, sweet, with little pulp. Vine thoroughly hardy and a strong grower. Free from mildew.

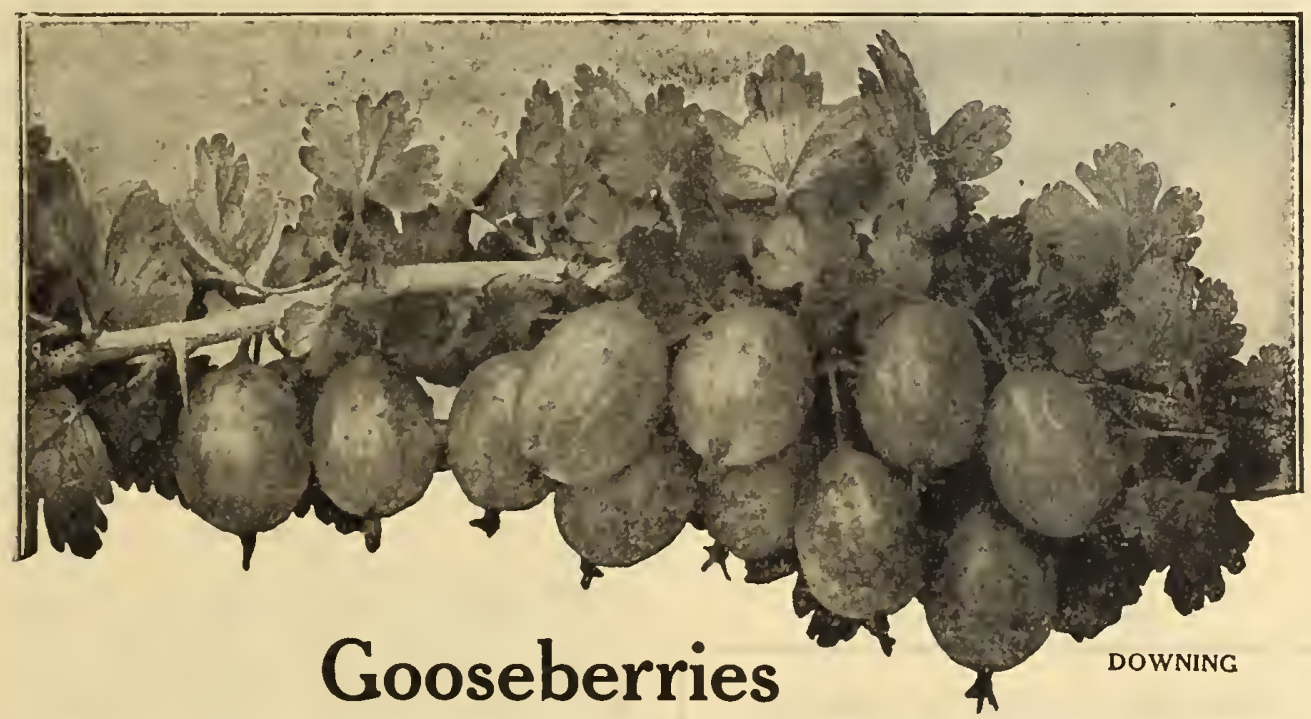

The Gooseberry is a northern plant, and seldom fruits well south of Maryland except in the high mountain sections. It grows best in a cool climate and moist soil. The plants may be set in rows from 5 to 6 feet apart and 4 feet apart in the rows and cultivated both ways for the first year or two. Little pruning is required and that is mainly to remove the stunted shoots and keep up a supply of vigorous new shoots from the base. Spraying with bordeaux mixture will keep down mildew, but mildew may be prevented in a great measure by keeping the head of the plant open and not allowing it to get crowded with shoots that are not needed.

Price o. Cooseberries except as noted : all strong, 2 year -lants, 18 each, $\$ 1.50$ per 10 , $\$ 12.00$ per 100 .

Parcels Post Prepaid-3c extra each, 20c per 10.

\section{Downing. Large; handsome, p a l e} green, and of splendid quality for both cooking and table use; bush a vigorous grower and usually free from mildew.

Industry. Berries of largest size, exIndustry cellent flavor, pleasant and rich: dark red color when fully ripe. Strong upright grower and immense cropper, not liable to mildew. $18 \mathrm{c}$ each. $\$ 1.65$ per 10 . $\$ 15.00$ per 100.

Smith's Improved. Large, pale greenish yellow, skin thin, of excellent quality. Bush moderately vigorous and excessively productive.
Houghton's. Medium size, pale red, tender, sweet and good; very productive.

Josselyn. Fruit large size, smooth, prolific, and hardy, of best quality. A wonderful cropper and strong grower.

Chautauqua. This is one of the larggrown. The bush is vigorous, stout, upright grower, with foliage large, glossy, dark green: fruit very large, smooth-veined, of yellowish color when fully ripe; skin thick; flavor very sweet. $18 \mathrm{c}$ each. \$1.65 per 10, \$15.00 per 100. 


\section{Currants}

This is one of the fruits that no garden should be without. It also commands a ready sale at a good price in the market; will do well in most any soil, but responds generously to good soil and cultivation. Plant four feet apart each way; prune out old wood so that the remaining shoots will have room to grow; if bothered with currant worm apply white hellebore to the leaves when damp.

\section{PRICE OF CURRANT}

2 Year No. 1

Perfection, 2 Year No. 1

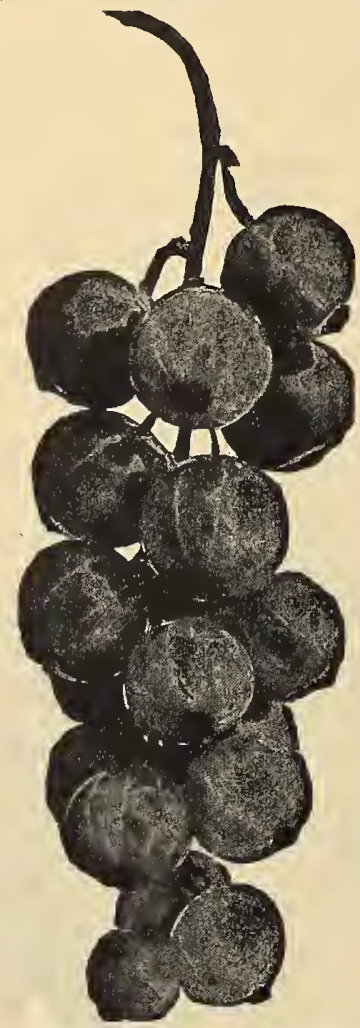

PERFECTION CIJRRANT

\section{Gurrant Gollection No. 1}

10 Strong 2 year Bushes, for 90 cents

3 Fay's Prolific, 3 White Grape, 2 Cherry, 2 Pomona

Bargain Price 90 cents. Catalogue Price \$1.25

$\begin{array}{lrr}\text { EACH } & \text { TEN } & \text { HUHDRED } \\ .17 & \$ 1.25 & \$ 8.00 \\ .20 & 1.75 & 12.00\end{array}$

Perfection. Beautiful, bright $r e d$, larger than Fay's, holding its size to end of bunch; a great bearer, superior to any other large sort. Awarded gold medal at the Western New York Horticultural Society.

Cherry. Berries very large, deep red; acid; bunches short; vigorous and productive. A reliable old market variety.

Fay's Prolific. The leading market variety. Extra large stems and berries; uniform in size; color, bright red.

London Market. Plant vigorous, with perfect foliage and enormous cropper; is large in both bunch and berry; one of the best for garden or market.

Pomona. Medium size; clear, bright red, excellent quality, hangs well on the bush, holds up well on market; is one of the best for shipping.

White Grape. Large,yellowish white,sweet, excellent quality. Best white variety.

Victoria. Large, bright red, bunches extremely long; berries medium size, of excellent quality, very productive; good market sort. Ripens late.

Red Cross. One of the best currants Red on the market. Ripens in mid-season and produces an enormous quantity of fruit; flavor mild and pleasant. The leaves of the plant are so dense as to hide the canes from view. The growths very vigorous and hardy.

Wilder. Ripens the same time as Fay's Prolific, and hangs on the bush much longer; fully as prolific and is in every way as profitable. A popular variety both for table and market. It is one of the stongest growers and one of the most productive varieties on our list. Bunches and berries large, bright and attractive red even when dead ripe. Hangs on the bush in fine condition for handling as late as any known variety.

Black Champion. Bush vigorous and productive; fruit average above medium; pulp nearly sweet, mild flavor. A dependable variety for general culture.

\section{Asparagus}

Plant in rows three feet apart, eight to ten inches apart in the row. Do not cut for use until second year.

Price of Asparagus, strong 2 year roots, 25 for 75 cents, 100 for $\$ 1.50,1000$ for $\$ 8.00$.

Conover's Colossal. The standard old variety, of large size and good quality.

Palmetto. Earlier than Conover's, a strong

\section{Rhubarb or Pieplant}

Plant four feet apart, in good, rich, deep soil

Linneaus. Large, early, tender and fine. The standard variety for market and garden. $15 \mathrm{c}$ each, $\$ 1.00$ per 10 . 


\section{Raspberries}

Will do well on most any soil that is moderately rich; keep well cultivated and free from weeds. As soon as they are done bearing each year, cut out the old wood to give more vigor to the young canes. Plant in rows five feet apart, three feet in rows.

Price of all Raspberries, except as noted, 50c per $10, \$ 2.50$ per $100, \$ 20.00$ per 1000 . Raspberries by parcel post prepaid, ic extra each.

\section{Yellow Variety}

Golden Queen. A beautiful large golden yellow berry; canes hardy, of strongest growth, productive; fine for table use.

\section{Black Varieties}

Eureka. Very early, large, fine quality. Hardy and good market variety.

Gregg. Very productive, large size. The standard late market variety.

Kansas. Strong vigorous grower, bearing immense crops; good quality, the standard midseascn variety.

Plum Farmer. Berries thick-meated with a bloom similar to Gregg. It ripens very early, maturing its crop in a very short period makes it one of the most profitable of the early market varieties.

Black Diamond. Fruit nearly as large as Kansas, firm and of high quality. It is said to be the sweetest of the black raspberries. Extremely popular in the berry sections of this state.

Ohio. One of the old standard varieties that still retains its favor; large size; good quality; extremely hardy.

Cumberland. A healthy, vigorous Cumer; fruit very large, firm, quality about the same as Gregg. Keeps and ships well. The most profitable market variety.

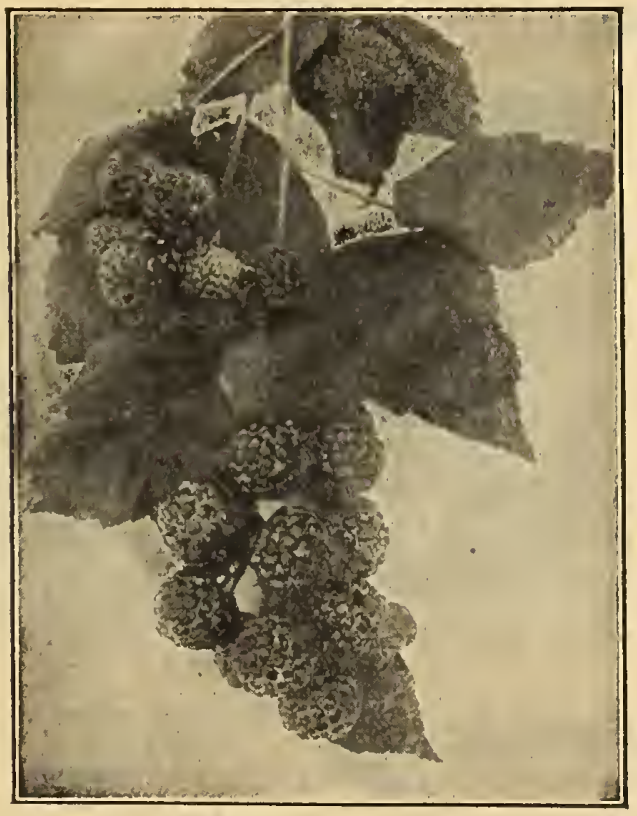

CUMBERLAND

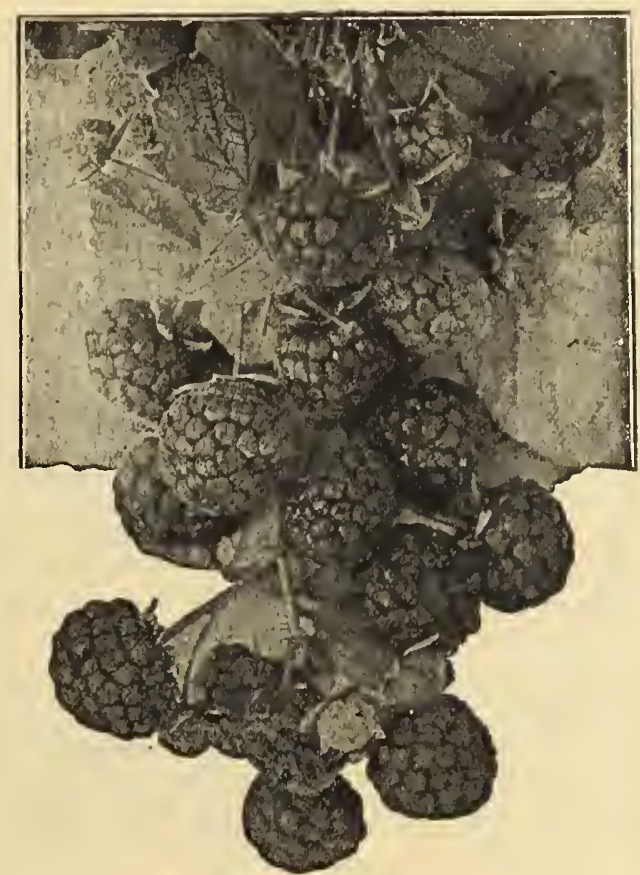

ST. REGIS EVERBEARING

\section{Red Varieties}

Cuthbert. A remarkably strong, hardy variety; medium to large, crimson. The most reliable late market variety.

Columbian. Fruit very large, purplish Color, rather soft, rich sprightly flavor, best for canning, etc. Bush a very strong grower, and great producer.

King. Plant a strong grower, very hardy and productive; berry large size, bright scarlet color, is firm and a good shipper; the best early red.

Haymaker. An enormous producer, of the Columbian type; fruit later and a little more acid.

St. Regis. This variety promises to be ditions to the list of Red Raspberries. It succeeds on all soils, whether light and sandy or on heavy clay; the canes are of a stocky, strong growth, with a great abundance of dark green foliage. Plants set in spring will give a small crop the following, and two crops each year after. In size, quantity, and quality the fruit is equal to any of the other raspberries. 


\section{Blackberries}

Plant on land moderately rich. Rows seven feet apart, three feet in a row; cultivate shallow. Cut out the old wood each year.

Price of Blackberries, 60c per $10, \$ 3.00$ per $100, \$ 22.00$ per 1000

Blackberries by Parcel Post Prepaid, 1c Extra Each

Snyder. Medium size, hardy and producSive; no hard, sour core. The best blackberry for all purposes.

Eldorado. The vines are very vigorous Eldorries large, jet black, borne in large clusters and ripen well together; they are very sweet, melting and pleasant, have no hard core, and will keep a week or more after picking.

Rathbun. Fruit is sweet and luscious without hard core, of extra hígh flavor, jet black, small seeds; fruit of very large size.

Blowers. A new variety of Snyder type, it is very prolific; berry larger than Snyder but not so good flavor. Canes very hardy.

Early Harvest. Not entirely hardy; one of the best where it succeeds. Its earliness, being one of the first to ripen, combined with good shipping qualities, make it very profitable. Fruit medium size, black, of good quality.

Erie. Large; high quality; vigorous and

Erie. early; very hardy and productive.

Wilson Junior. Fruit of good size, very early, beautiful dark color, of a sweet excellent flavor, and very productive. Plants hardy.

Ward. This variety seems to be very where it was found growing wild, although it is said to be a seedling of Kittatinny. The plant is a very vigorous grower and bears enormous quantities of fruit. Perhaps no other variety of recent introduction has attracted so much attention as this one. The berries are large, rich, sweet, tender and without a hard core. ' $\mathrm{l}$ 'he Ward is an excellent Blackberry.

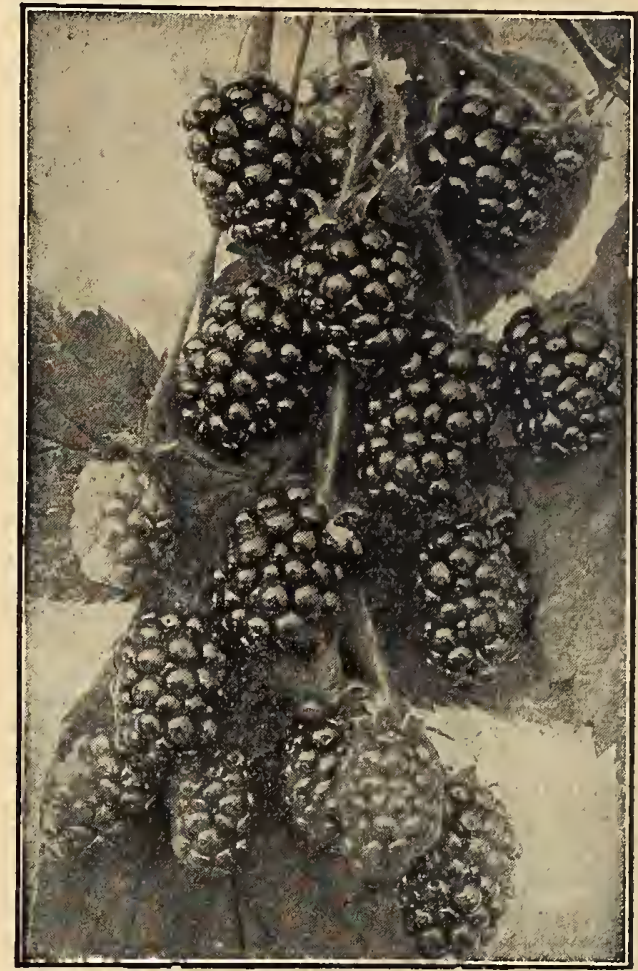

WARD

\section{Strawberries}

Any good soil will grow Strawberries; the better the soil the larger and better the crop. For field culture plant $3 \frac{1}{2}$ feet apart, 15 to 18 inches in the row. For garden 15 to 18 inches each way.

NoTE: Do not order Strawberry plants shipped by freight. Strawberry plants should go by express, or small lots by mail. When desired by mail add postage at the rate $20 \mathrm{c}$ per 100 . Always state plainly whether the Strawberry plants are to be sent by mail or express.

Price of Strawberries: $40 \mathrm{c}$ per $10,75 \mathrm{c}$ for 25 , 100 for $\$ 1.50,1000$ for $\$ 8.00$.

Early Varieties. Michaels Early (Per.), Cresent (Imp.), Klondike (Per.), Lady Thompson (Per).

Medium Varieties. Corsican (Per), Senator Dunlap (Per), Glen Mary (Per.), Bubach (Imp), Haverland (Imp.), Marshall (Per), Duncan (Imp), Potomac (Per), Norwood (Per), Three W's (Per.), Parson's Beauty (Per), Chipman (Per).

Late Varieties."Brandywine (Per, , Sample (Imp,), Myers No. I (Per), Parker Farle (Per.), Aroma (Per.), Stephens Late Champion (Per.), Gaudy (Per).

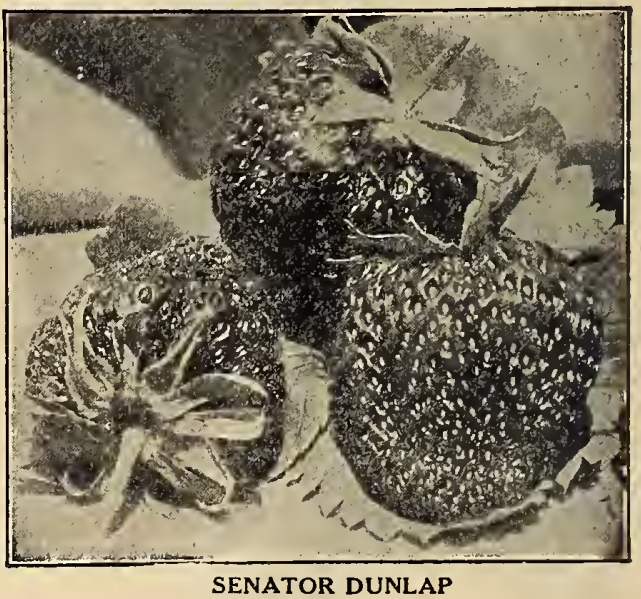

\section{Fall Bearing Strawberries}

Price of Fall Bearing Strawberries, 80c per $10, \$ 1.25$ per $25, \$ 4.00$ per $100, \$ 15.00$ per 1000

We can supply the three most profitable varities as follows, Superb (Per.), Americus (Per.), Productive (Imp.) 


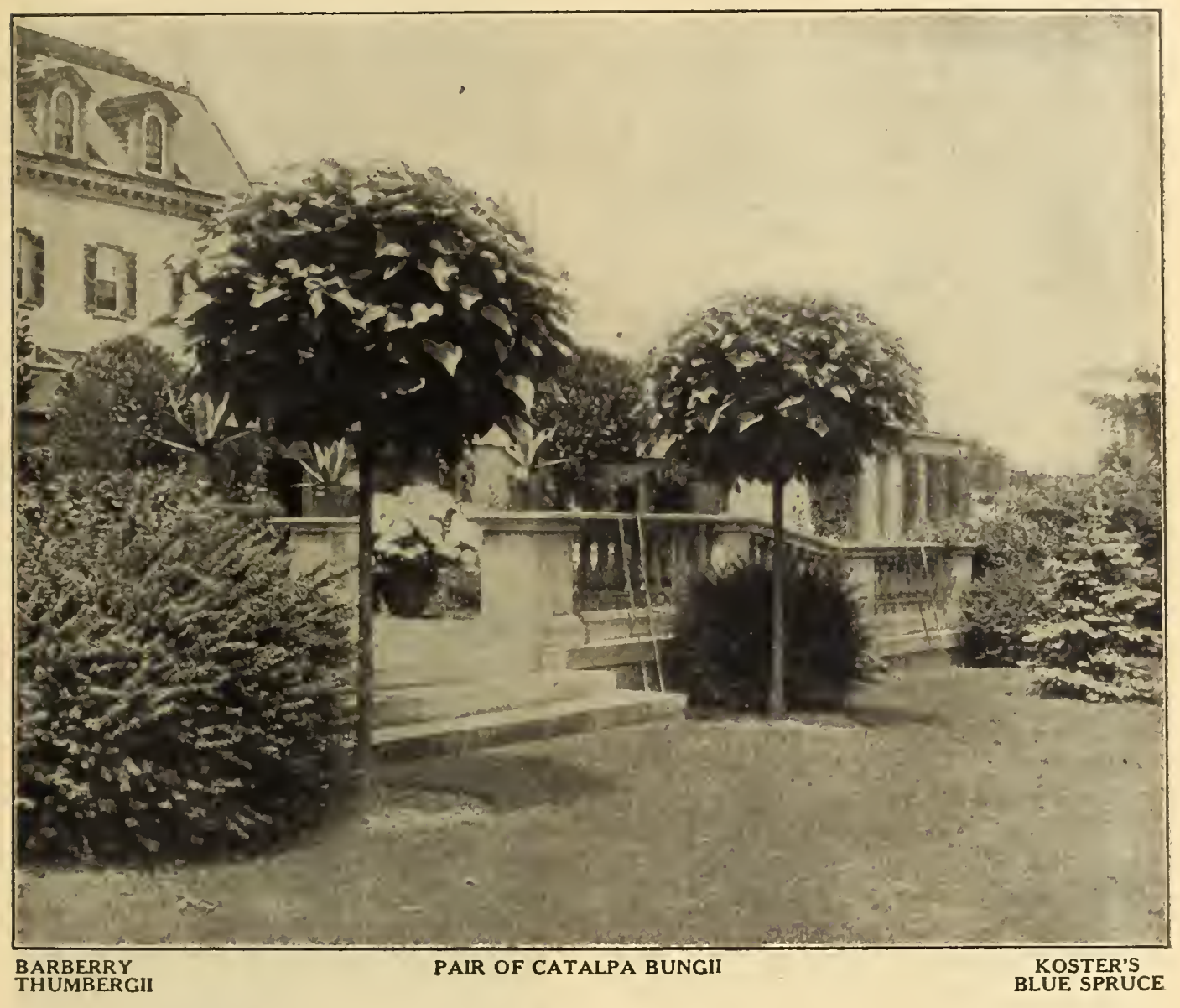

\section{Ornamental Department}

Catalpa Bungii. (Umbrella Catalpa). Grafted on stems 6 to 8 feet high, it makes an umbrellashaped top without pruning. A very desirable ornamental for the lawn, or along the driveway. Perfectly hardy. 6 to 8 feet $\$ 1.00$ each.

Bechtels Crab. (Double Flowering.) The flowers are a beautiful pink ; very sweet scented; two inches in diameter; blooms in May. Grows twenty to thirty feet tall. 3 to 4 feet 75 c each.

Double White Thorn. The thorns deserve to be classed among the most beautiful flowering trees. The foliage is varied; the flowers are vary showy and often highly perfumed. The double white makes a striking contrast when palnted with the double scarlet. 4 to 5 feet $75 \mathrm{c}$ each.

Double Scarlet Thorn. Flowers bright carmine red. Should be planted to contrast with the double white. 4 to 5 feet $75 \mathrm{c}$ each.

Prunus, Pissardi. (Purple Leaved Plum). A small purple leaved tree for the lawn, that retains its color perfectly throughout the entire season. It is very ornamental and beautiful. 4 to 5 feet $35 \mathrm{c}$ each; $\$ 3.00$ per 10 .

Prunus Triloba. (Double Flowering Plum). A charming shrub of vigorous growth. Blossoms very early in spring before the leaves appear, and produces a mass of very double light pink blossoms. 2 to 3 feet 35 c each; $\$ 3.00$ per 10 .
Beech. Purple Leaved. Makes an elegant, bushy tree for the lawn; the foliage in the spring is deep purple, later changing to crimson, and in autumn a dull purpilsh green. 4 to 5 feet $\$ 1.00$ each.

Catalpa, Speciosa. This is an ornamental tree that is valuable for timber, fence posts, railroad ties, etc. One of the most rapid growers, has large, heart-shaped leaves, very large, showy, whitish flowers.

6 to 8 feet, 50 c each, $\$ 4.50$ per 10 .

8 to 10 feet, 60 c each, $\$ 5.00$ per 10 .

American Linden or Basswood. A rapid growing large sized, beautiful native tree with large leaves. The flowers yield a delicate perfume in addition to many other valuable qualities that the trees possess. 8 to 10 feet $75 \mathrm{c}$ each; 6 to 8 feet $50 \mathrm{c}$ each.

European Linden. A very fine tree for street. planting or for the lawn; it grows to large size with large leaves and fragrant flowers. 8 to 10 feet $75 \mathrm{c}$ each ; 6 to 8 feet $50 \mathrm{c}$ each.

Oriental Plane or Sycamore. A large round headed wide spreading tree, regularly formed, usually with a short thick trunk. A beautiful and majestic shade tree. Will do well in most any kind of soil; even near the water. A good street tree; succeeds where others fail. 8 to 10 feet $75 \mathrm{c}$ each; 6 to 8 feet $60 \mathrm{c}$ each. 
Maple, Norway. Supposed to be the best of the maples for street planting; grows to large size, with head usually round and perfect in form, with deep green foliage.

Ash Leaf Maple. A very rapid growing variety, with handsome light green foliage and spreading head, very hardy, desirable for street planting, succeeds in many sections where other varieties do not thrive.

Sugar or Rock Maple. Straightest and most upright grower of all the Maples : it is of grand proportions, and often reaching the height of 100 feet, it roots deeply allowing the grass to grow up close around the trunk, and it does not upheave the sidewalk as bad as other varieties when used for street planting.

Wiers Cut Leaf Maple. A silver maple with beautiful dissected foliage. Of rapid growth, with slender drooping branches, giving it a very graceful appearance. Should be in every collection a fitting mate for cut leaf weeping birch.

Maple, Silver. Of excellent rapid growth, and desirable where quick shade is wanted.

$\begin{array}{rrr}\text { Price of above five Maples } & \text { EACH } & \text { IEN } \\ 10 \text { to } 12 \text { feet } & \$ 1.25 & \$ 10.00 \\ 8 \text { to } 10 \text { feet } & 1.00 & 8.50 \\ 6 \text { to } 8 \text { feet } & .90 & 7.50\end{array}$

Poplar Carolina. The most rapid growing tree we have; especially desirable where quick returns are wanted; it is a vigorous, healthy, native tree, pyramidal in form with large, glossy leaves valuable for park or street planting.

Lombardy Poplar. Well known for its erect, rapid growth and spike-like form; not as good for shade as the Carolina.

\begin{tabular}{rrrr} 
Price of above two Poplars & EACH & \multicolumn{1}{c}{ IEN } & HUNDRED \\
10 to 12 feet & $\$ .75$ & $\$ 6.00$ & $\$ 50.00$ \\
8 to 10 feet & .60 & 5.00 & 40.00 \\
6 to 8 feet & .50 & 4.00 & $\mathbf{3 0 . 0 0}$
\end{tabular}

Elm, American. One of the very best shade trees for lawn, street or park; has wide spreading head and graceful drooping branches; attains very old age and large size.

$\begin{array}{rrr} & \text { EACH } & \text { IEN } \\ 10 \text { to } 12 \text { feet } & \$ 1.00 & \$ 9.00 \\ 8 \text { to } 10 \text { feet } & .75 & 6.50 \\ 6 \text { to } 8 \text { feet } & .50 & 4.50\end{array}$

Horse Chestnut. A very beautiful well known tree with round dense head, dark green foliage, with an abundance of showy flowers in spring. 6 to 8 feet 75 cents each; $\$ 6.50$ per 10 .

Tree Hydrangea. It forms a graceful low headed tree, does not attain a height of more than ten or twelve feet; blooms from August first until frost; fine for lawn decoration, either single or in masses. 3 to 4 feet $75 c$ each; $\$ 6.00$ per 10 .

Birch, American White. A large, vigorous upright tree with smooth white bark and handsome foliage. Very effective when planted in front of evergreens, to afford strong contrast. Its broad leaves make it a better tree for shade than the Cut Leaved. 5 to 6 feet $60 \mathrm{c}$ each; 6 to 8 feet 75 cents each.

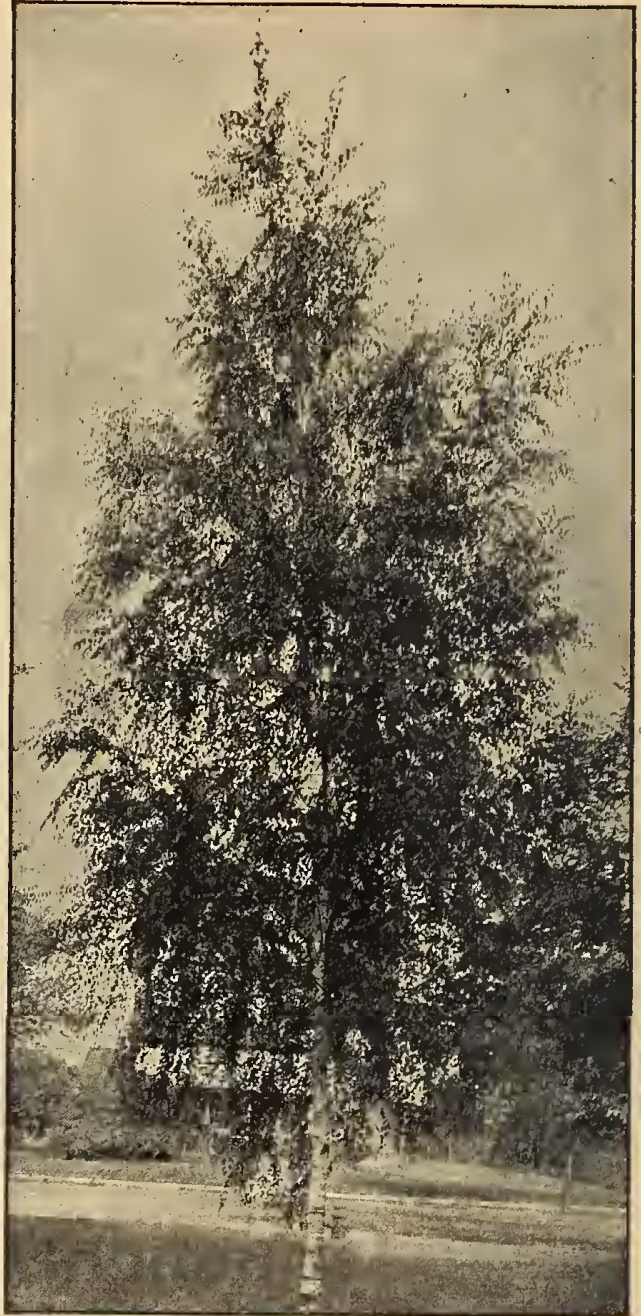

CUT-LEAF WEEPING BIRCH

Birch, Cut Leaf Weeping. An elegant erect tree, with slender drooping branches and fine cut leaves. A magnificent variety and worthy of a place on every lawn. 5 to 6 feet $\$ 1.00$ each.

Mulberry, Tea's Weeping. A very thrifty, vigorous grower, perfectly hardy, forming a natural umbrella shaped top or heard, with handsome foliage. 5 feet $\$ 1.25$ each.

Willow, Kilmarnock. An exceedingly graceful tree, with large glossy leaves and a perfect umbrella head. 4 to 5 feet $\$ 1.00$ each.

E1m, Camperdown. Its vigorous, irregular branches which have a uniform weeping habit overlap so regular that a compact, roof-like head is formed. It is a beautiful ornamental. 2 year heads $\$ 1.25$ each.

Willow, Babylonian Weeping. A rapidgrowing, hardy tree, thriving in any moist soil. The Willows are valuable and interesting subjects, on account of their graceful aspect. Most effective when planted on the banks of streams or ponds. 7 to 8 feet $50 \mathrm{c}$ each.

Willow Wisconsin Weeping. A large tree with long, drooping branches, similar to Babylonica, but much hardier. 7 to 8 feet. $50 \mathrm{c}$ each. 


\section{Nut Trees}

Until recently little attention has beer given to Nut Fruits; this should not be so as considerable profit may be derived from their cultivation. the growing of nut fruits is very simple in itself, requiring only ordinary labor and little expense. Many kinds make good shade trees in addition to the value of the wood and nuts.

Chestnut, American Sweet. This is the well known native variety, with medium size sweet nuts. It is the only variety of Chestnuts that can rightfully be called sweet. It seldom fails to produce a good crop of nuts each year. and there is always a ready market at good price. 4 to 5 feet $50 \mathrm{c}$ each; $\$ 4.50$ per 10

Chestnut, Spanish. Not so sweet as American but larger in size. Handsome round-headed tree, producing large crops; makes good ornament for lawn. 4 to 5 feet $50 \mathrm{c}$ each.

Butternut. Produces large long nuts, with rich, sweet, oily kernel; very nutritious. 4 to 5 feet 50 c each.

English or Madeira Walnut. The largest and most delicious of all the walnut group; produces large crops of thin-shelled, meaty and desirable nuts, which are al ways in good demand at high price. Makes nice ornamental trees for the lawn. 2 to 3 feet $50 \mathrm{c}$ each.

American Black Walnut. The common American Black Walnut is a native tree of fast growth and large size. The timber is exceedingly valuable, and is even exported to foreign countries. Trees produce heavy crops of large oily nuts, which are readily sold at a fair price. 4 to 5 feet 50 c each.

\section{Evergreens}

Trees dug with ball of earth about the roots and tightly sewed in burlap will stand transportation and transplanting with little risk of loss. In planting it is not necessary to remove the burlap. Place tree in properly prepared hole, cut burlap in several places, firm earth tightly about ball of roots, water, and mulch with leaves, straw or other coarse litter.

Arbor Vitae, American. One of the very best evergreens for hedge or single; it grows rapidly and is very dense.

$\begin{array}{llrr} & \text { EACH } & \text { TEN } & \text { HUMDRED } \\ 2.3 \mathrm{ft} . & .60 & \$ 5.00 & \$ 45.00 \\ 1 \mathrm{r} / 2.2 \mathrm{ft} . & .50 & 4.00 & 35.00\end{array}$

Norway Spruce. A lofty, elegant tree of pyramidal habit, exceedingly picturesque and beautiful; good as a hedge plant.

$\begin{array}{lrrr} & \text { EACH } & \text { TEN } & \text { HUNDRED } \\ 2-3 \mathrm{ft} & .60 & \$ 5.00 & \$ 45.00 \\ 1 \mathrm{~J} / 2-2 \mathrm{ft} & .50 & 4.00 & 35.00\end{array}$

Irish Juniper. Very erect and tapering in its growth, forming a column of deep green foliage; a pretty little tree or shrub, and for its beauty and hardiness is a general favorite, $1 \mathrm{x} / 2-2 \mathrm{ft}$., $60 \mathrm{c}$ each.

Colorado Blue Spruce. A rare elegant tree with foliage of rich blue. Tree usually has a symmetrically shaped narrow pointing or rounding top; is hardy and quick growing. 2-3 ft., $\$ 2.00$.

Koster's Blue Spruce. (Grafted.) Foliage an intense silvery blue, a very dense, rapid grower with regular slim branches. Very rare and distinct. $2-3 \mathrm{ft}$., $\$ 3.00$.

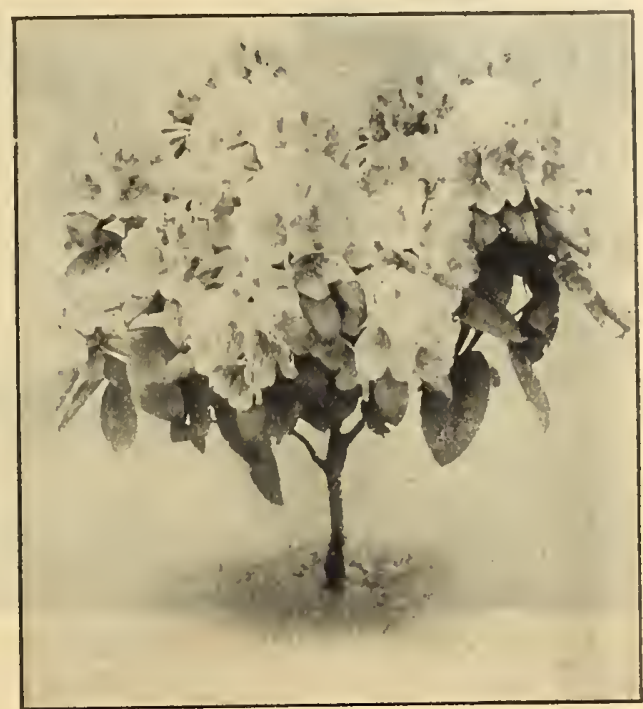

RHODODENDRON

Rhododendron The huge cluster of flowers in many shades of pink, violet, rose, purple and delicate creamy white, give them first rank among evergreen shrubs. There is no more attractive feature of a fine country place than the rich bloom of Rhododendrons in the latter part of May and early June. Rhododendrons are most effective when planted in large beds or groups. They will grow in any good soil, but do best in a sheltered position where the soil is deep, well drained and mulched with leaves. In hot dry weather give the ground a good soaking of water about once a week. Should be protected in winter with leaves, small brush and coarse manure.

The plants we offer are strong and bushy, well set with buds and will blossom the first year. Pink, Violet, Rose, Purple and White. $\$ 1.25$ each, $\$ 10.00$ per 10 .

\section{Hedge Plants}

Privet, California. Of all ornamental Hedge plants this is the most popular, and more of it is planted than all others combined. Its foliage is a rich dark green, and is nearly evergreen, remaining on the plant until midwinter. It is of free growth and succeeds under the most adverse conditions, such as under dense shade of trees, where other plants would not exist.

\begin{tabular}{lrrrrr}
\multicolumn{5}{c}{ Strong 2 Year Well Branched } & B \\
& EACH & IFH & HUNDRED & IHOUSAND \\
$18-24$ in. & .10 & .75 & $\$ 5.00$ & $\$ 35.00$ \\
$2-3$ feet & .15 & 1.00 & 6.00 & 45.00
\end{tabular}

Privet, Amur River. Resembles California in habits of growth, but is hardier and should be planted in sections where the California is liable to winter-kill. 18 to 24 in. $15 \mathrm{c}$ each; 10 for $\$ 1.25 ; 100$ for $\$ 8.00$.

Barberry, Thunberg's, Of spreading habit, growing extremely thick right from the base. The leaves are small, light green, and toward. fall assume rich, brilliant colors, the fruit or berries become scarlet; absolutely hardy.

\begin{tabular}{lrrr}
\multicolumn{4}{c}{ Strong 2 Year Well Branched } \\
& EACH & IFH & HUMDRED \\
$18-24$ in. & .20 & $\$ 1.75$ & $\$ 15.00$ \\
$12-18$ in. & .15 & 1.40 & 12.50
\end{tabular}




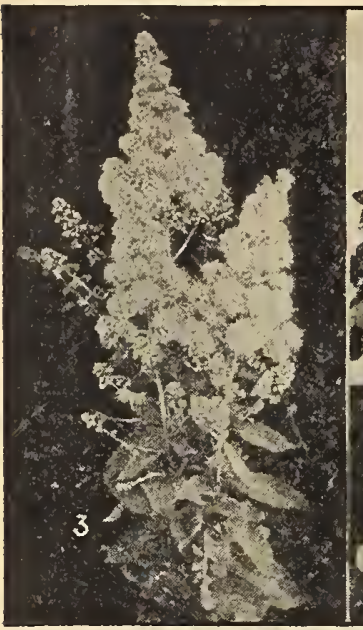

SPIRAEA

BILLARDI

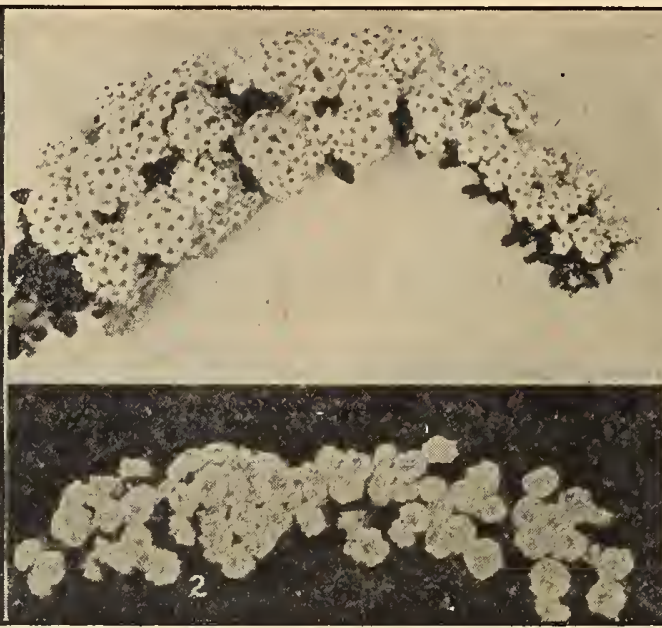

SPIRAEA VAN HOUTTEI Above SPIRAEA THUNBERGII Below

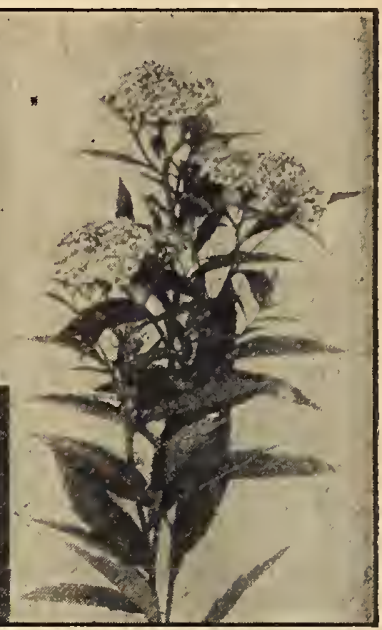

SPIRAEA

ANTHONY WATERER

\section{Hardy Flowering Shrubs}

\section{Price except as noted}

EACH TEM

Strong 2 year 2 to 3 feet

.25

$\$ 2.00$

Spiraea Van Houttei. The grandest of all spiraeas. It is a beautiful ornament for the lawn at any season, but when in flower it is a complete fountain of white bloom, the foliage hardly showing. Clusters of twenty to thirty flat white florets makeup the raceme, and these clusters are set close along the drooping stems. Perfectly hardy and an early bloomer.

Spiraea, Billardi. A hardy, free growing shrub. During July every branch and twig is tipped with a spike of beautiful blood-red Howers 4 to 6 inches in length. A distinctive and beautiful flower and shrub.

Spiraea, Anthony Waterer. A beautiful dwarf shrub that throughout the season continuously yields an abundance of rich crimson flowers. Two feet when fully grown.

Thunberg's. (Thunbergii). A Japanese species of small size, with narrow linear leaves and small white flowers.

Althea or Rose of Sharon. Bloom late in August and September, at a time when so few other shrubs are in blossom, flowers large and brilliant color; makes an elegant flowering hedge. Red, Purple, White and Variegated Leaved.

Lilac. A well known shrub that should be in every collection. Purple and white.

Weigelia Candida. Of vigorous haibit and erect growth a choice variety of pure white flowers, blooming in June, and to some extent all summer. Desirable for border; for grouping and make fine specimen plants for the lawn.

Weigelia Rosea. An elegant hardy shrub with fine rose-colored flowers. Blossoms in June.

Weigelia Eva Rathke. One of the most attractive and very distinct varieties; flowers deep carmine red. All Weigelias $25 \mathrm{c}$ each.

Honeysuckle Tartarian. Bush form; they have bright and pretty fragrant flowers, followed with showy berries that last through the fall. Make desirable and attractive hedges, borders or single specimens. Colors, White, Pink and Red.

Syringa. (Mock Orange.) Very hardy, vigorous grower with very fragrant showy white flowers.

Deutzia Crenata. A hardy, tall-growing shrub with double pink flowers; blossoms in June. The deutzia is among the most attractive of our flowering shrubs.

Deutzia, Pride of Rochester. Very early, large double white flowers profuse bloomer and vigorous grower; a week earlier than Crenata.

Deutzia Gracilis. A dwarf variety covered with white flowers in June.

Golden Elder. One of the best of the colored shrubs foliage a rich golden yellow. One of these plants in a bed, row border, or on the lawn is a very conspicuous feature.

Snowball, Common. A well known favorite shrub of large size; bears clusters of pure white flowers in May and June.

Calycanthus. (Sweet scented shrub.) Partiticularly desirable on account of the fragrance of the wood. Flowers are of a rare chocolate color, with an agreeable odor.

Barberry, Purple Leaved. A highly ornamental shrub that is hardy everywhere; has very showy foliage, flower and fruit; used in some places for hedges.

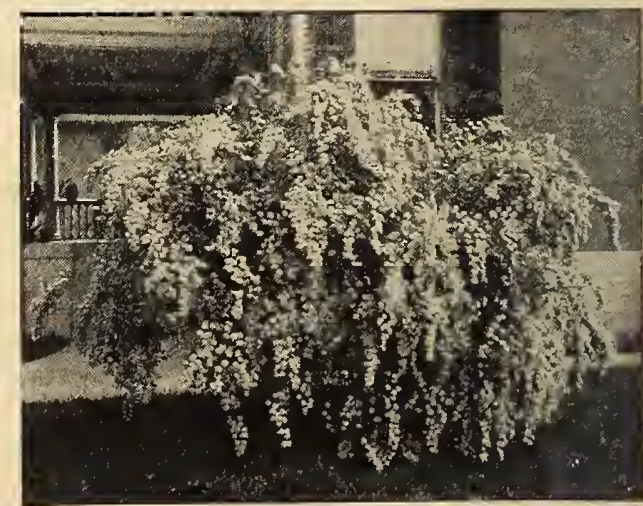

A Bush of Spiraea Van Houttei in Full Blomm 


\section{Hardy Flowering Shrubs-_-Continued Price Except as Noted}

EACH

Strong, 2 year 2 to 3 feet

.25

IEN

Hardy Hydrangea (Paniculata Grandiflora.) We urge our friends to plant the Hydrangea. Plant it for the following reasons: It is hardy, encluring the severest winters out doors without protection. It is easily transplanted, not one in a thousand dying: it never fails to blossom the first year planted; no matter how small the plant, it immediately buds out in great profusion of flowers, many of them as large as the head of a full grown child. When the specimens first open they are greenish white, later they turn to a pure white, and still later to a delicate pink. The Hydrangrea should be cut back at least one-half of each season's growth in order to get the largest specimens. To get the best results, make the soil rich, it will grow anywhere and on any soil. 25c each; $\$ 2.25$ per 10.

Hydrangea arborescens grandiflora alba. Also called "Snowball Hydrangea" and "Hills of Snow." The blooms are of the very largest size, of pure snow-white color. One of its most valuable characteristics is its coming into hloom just after the passing of all the early spring shrubs, while its long season of bloom, from

- early June through August, renders it doubly valuable to every owner of a garden; perfectly hardy. 35c each.

Barberry Thunbergii. A pretty plant of dwarf habit form Japan. Very graceful and its foliage turns to a beautiful red in the fall. All Barberries make very fine hedges.

Barberry Vulgaris (Common Barberry.) A handsome deciduous shrub, with yellow flowers in term:nan, drooping racemes in May or June, followed with orange scarlet fruit.

Forsythia (Golden Belle.) This is a pretty shrub of medium size. The flowers are drooping yellow, and appear very early in spring before the leaves. Among the very best early flowering shrubs.

Purple Fringe (Smoke Tree.) A very large shrub with feathery purple flowers which gives a smoky effect to the tree when in bloom. The blossoms come in July and generally cover the whole tree, remaining all suminer. 35c each; $\$ 3.00$ per 10.

White Fringe. A small native tree or shrub, of roundish form, with large glossy leaves and drooping racemes of pure white Howers, having narrow fringe-like petals. Blossoms in May or June. A good lawn tree. 35c each; $\$ 3.00$ per 10.

Butterfly Bush. Seems to attract butterflies in large numbers. It produces long, graceful stems which terminate in tapering panicules of beautiful lilac-colored flowers that are of $\mathrm{min}$ ature size and borne by the hundreds on a flower head which is often ten inches long. It blossoms from early sunımer until frost; fine for cutting. 2 to $3 \mathrm{ft}$. $30 \mathrm{c}$ each.

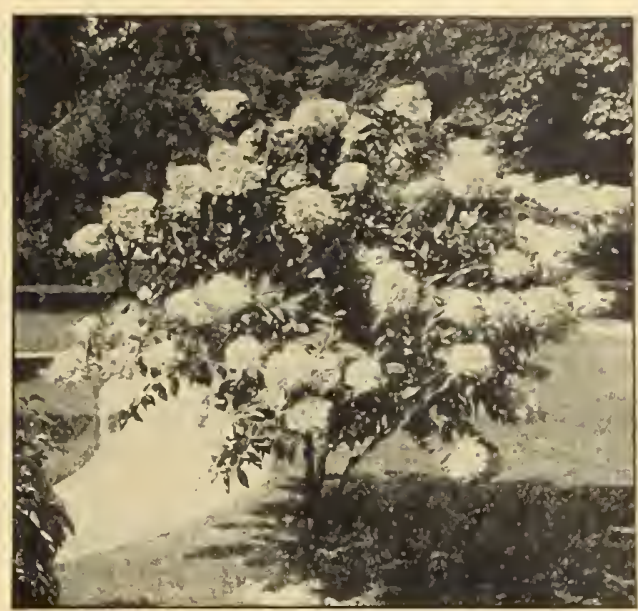

HARDY HYDRANGEA BUSH

Cornus Siberica. (Dogwood) Grows 6 to 8 feet high, with fine white flowers, succeeded with a fall crop of ornamental berries. Very conspicuous and ornamental in winter when the bark is blood red. 2 to $3 \mathrm{ft}$., $30 \mathrm{c}$ each.

Japan Quince. Very early in the spring this fine old shrub is completely covered with dazzeling scarlet flowers, followed by small quinceshaped fruit which are quite fragrant. Grows bushy and dense with protecting thorns. Fine as single shrub, for borders and for hedge. 2 to $3 \mathrm{ft}, 25 \mathrm{c}$ each, $\$ 2.00$ per $10, \$ 15.00$ per 100 .

Racemosus. (Snowberry) A well known shrub with small pink flowers and large white berries that harig on the plant through most of the winter. 2 to $3 \mathrm{ft}$., $25 \mathrm{c}$ each, $\$ 2.00$ per 10 .

Cut-Leaved Elder. A beautiful variety with deeply and delicately cut dark green foliage. It is valuable on account of its beauty, hardiness. and rapid growth, and the ease with which it is transplanted. We consider it one of the besi cut-leaved shrubs in cultivation. 2 to $3 \mathrm{ft} ., 25 \mathrm{c}$ each, $\$ 2.00$ per 10 .

Spiraea Opulitolio. (Nine Bark) Growth upright attaining a heighth of 8 to 10 feet. Although the white heavy flower umbrels in June make the branches droop, old flower heads turn to dark red, and make a striking variety of colors at different stages of maturity, 2 to $3 \mathrm{ft}$., $25 \mathrm{c}$ each, $\$ 2.00$ per 10 .

A few dollars expended in Ornamental Trees, Shrubs, Roses, Vines, Hedging, etc., not only adds to the beauty of the home and pleasure of the present occupant, but adds many times its cost to the value of the property. We will be glad to advise you on your ornamental planting if you will state the size of your lot and the amount you wish to expend.

\section{FLOWERING SHRUB COLLECTION NO. 10} 10 Shrubs worth $\$ 2.00$. Collection Price $\$ 1.50$

1 Spiraea Van Houtte

1 White Honeysuckle

I Golden Elder
1 Spiraea A. Waterer 1 Deutzia P. of R.

1 Cut Leaved Elder
1 Hydrangea P. G.
1 Pink Honeysuckle

1 Syringa Mock Orange

1 Forsythia Golden Belle 
Paeonies. The rival of the rose in beauty and fragrance. The Paeonies after once planted will pretty near take care of themselves, and is one of the most popular of the hardy perennials. Plant in Spring or Fall. We have them in white, red and pink. Price of strong plants, 25c each. $\$ 2.00$ per 10 . By parcel post prepaid, 3c extra each.

Perennial Phlox. The finest of autumn flowers. Plant the roots in Fall or Spring and they will continue to send up shoots and flowers for many years. Plant Phlox in a row along the border of the driveway, or in beds on the lawn. It is hardy and succeeds in any climate. White, Red and Pink. Price of strong plants, $15 \mathrm{c}$ each, $\$ 1.25$ per 10 . By parcel post prepaid, 3c extra each.

1 Rudbeckia "Golden Glow." Grows j̃ to 7 feet and blooms from early summer until inost. Flowers golden-yellow. 10 c each ; $\$ 1.00$ per doz. Parcel Post prepaid, 3c extra each.

\section{Magnolia}

Their superior stateliness of form and splendor of growth combined with richness of foliage and lavish yield of fragrant flowers, all tend to place them in the foremost rank among hardy ornamental trees and shrubs. Their large, showy white, pink and purple flowers cover the trees in early spring before the leaves appear. Shipped with original ball of earth. $\$ 2.00$ each.

Soulangeana. One of the hardiest and finest. Its blossoms are 3 to 5 inches across, cupshaped, white and rosy violet. 4 to $5 \mathrm{ft}$.

Lennei. A hybrid variety of great beauty, flowers deep rose color. 4 to $5 \mathrm{ft}$.

Halleana. A pretty dwarf form with snowy white, semi-double flowers in April. Earliest of all Magnolias. 2 to $3 \mathrm{ft}$.

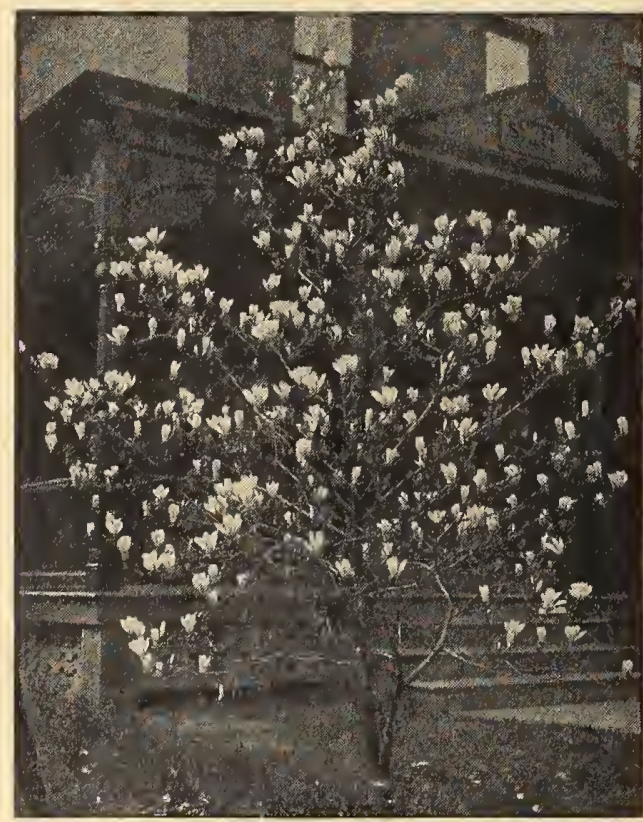

MAGNOLIA SOULANGEANA IN BLOOM

Have your trees reserved early, for shipment when you want them.

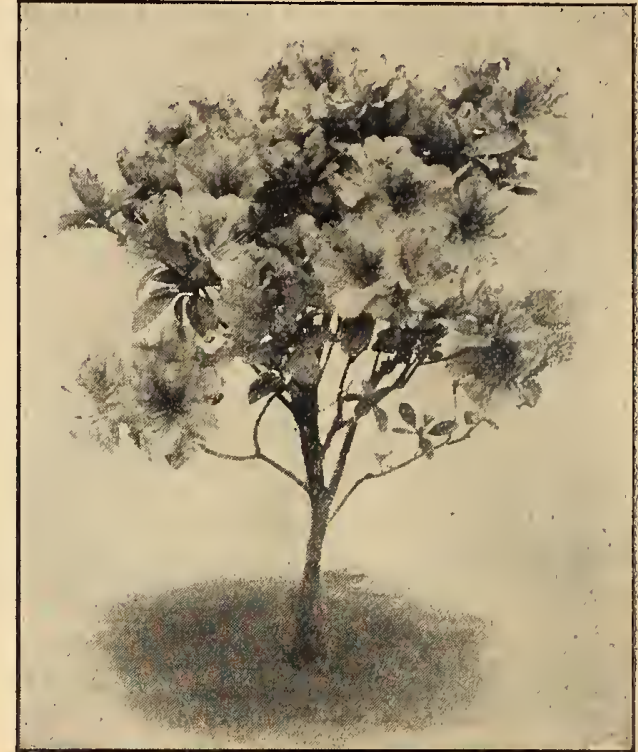

AZALEA

Azalea In early spring the Azalea are make the most gorgeous show of color; to be found among the deciduous shrubs. A very effective way is to mingle them with Rhododendrons. Both require about the same soil and treatment. The brilliant flowers of the Azalea set off the sombre foliage of the Rhododendrons before the latter come into bloom. A splendid assortment of colors in many shades of red, yellow, white and orange. The plants we offer are strong and bushy, well set with flower buds and will blossom nicely the first year.

Shipped with original ball of earth.

Extra well budded 15 to 18 inch. 50 c each, $\$ 4.50$ per 10 .

\section{Hardy Climbing Vines}

Hall's Japan Honeysuckle. Almost evergreen hardy and of strong growth. The flowers are fragrant, of a pure white changing to yellow, Strong plants. $25 \mathrm{c}$ each.

Ampelopsis Veitchii (Boston Ivy). This is one of the most beautiful ivies and the latest acquisition. It is a rapid grower and clings tenaciously to brick or stone walls, requiring no artificial fastening or training. It is hardy and thrives almost everywhere. Price, strong vines $35 \mathrm{c}$ each.

Aristolochia Sipho (Dutchman's Pipe.) Brownish flowers, resembling a miniature pipe: splendid for archways or verandas. 2 year, 50 cts. each.

Jackmanni Clematis. Flowers, when fully expanded, are from 4 to 6 inches in diameter; intense violet purple, with a rich velvety appearance. Price of strong plants $35 \mathrm{c}$ each.

Paniculata. Of very rapid growth, with handsome glossy foliage. The flowers are of medium size, fragrant, pure white. 25c each.

Chinese Wistaria. One of the most elegant and rapid growing of all climbing plants; attains an immense size, growing at the rate of 15 to 20 feet in a season. Has long pendulous clusters of flowers in May, June and in autumn. Purple, White and Blue. $35 \mathrm{c}$ each. 


\section{Roses}

Our Roses are all hardy two year field grown stock, sure to bloom the first year; in fact most of them have bloomed in the nursery before sending them out.

Planting. Plant 3 to 4 inches deeper than they stood in the nursery; pack the soil well around the roots; trim the shoots back to 6 or 8 inches, and shade from the sun until they start growing; a good way is to cover with newspaper weighted down to prevent blowing off. When the planting is finished a good soaking with water should be applied; then mulch with coarse manure.

\section{Hybrid Tea or Everblooming Roses}

This is a class of recent creation, embodying the delicate shades and peculiar fragrance possessed by the Tea Roses combined with the vigor and more pronounced pink and crimson shades of color previously confined to the Hybrid Perpetual class. In our opinion the Hybrid Teas will supersede all others because of their superior constitution and marvelously free flowering qualities. In a sentence it may be said they combine all the better traits of the two classes from which they sprang, altogether a great advantage. Almost all are highly perfumed, an attribute absolutely essential to a perfect Rose. They are ever-bloomers and hardy in all but the most rigorous climate.

Price Strong, 2 Year Plants Except as noted

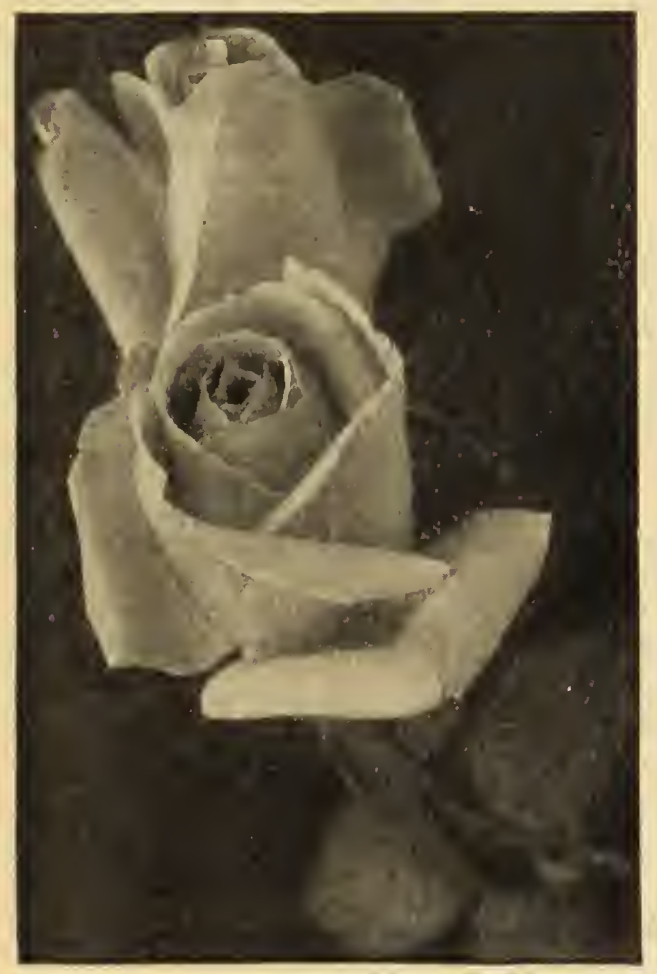

KILLARNEY

Killarney (Pink.) The finest pink rose ever introduced. In coloring it is especially beautiful, being an exquisite shade of deep seashell pink. The buds and flowers are of enormous size, the petals being frequently two and onehalf inches deep. This variety seems. to possess all the qualities that go to make up a perfectly everblooming rose. We have counted as high as thirty-five blooms and buds in different stages of development on a single two year bush in the nursery.

White Killarney. A sport from Killarney. Grand in every way. The white forcing rose of the century. Resembles the Pink Killarney in habits and freedom of bloom. Planted in the garden it comes with a delicate pink tinge that if anything adds to its beauty. A great acquisition and a really wonderful Rose.
EACH

IEN

$.40 \$ 3.50$

General McArthur. One of the best red roses of this class. Color crimson scarlet; the most beautiful shade of any garden or forcing rose offered; retains its brilliancy when ix panded into flowers of superb form.

Gruss an Teplitz. Bright crimson; fiery-red center; cup-shaped; semi double; flowers in clusters; so free in bloom as to present a blaze of scarlet.

Jonkheer Mock. One of the strongest growers of the H. T. class. Color: clear imperial pink. Flowers round and full.

Lady Hellingdon. At the Detroit Rose show in January, 1912, this was awarded the sweep stakes over all yellow Roses, also awarded the gold medal of the National Rose Society. A long slender pointed bud of brilliant deep, golden yellow ; at no stage of its development does it show a lighter color so common in all yellow roses but is always an even, deep intense golden-yellow. Price 50c each.

Madame Caroline Testout. Clear, bright satiny-pink; flowers very large and extremely showy.

Souvenir Du President Carnot. Superb in shape and exquisite in color; long beautiful pointed buds, developing into large, full and double flowers with thick, heavy shell-like. petals. A delicate flesh-white, shaded a trifle deeper at the center, very slightly suffused with fawn. Each individual flower distinctly apparent on a long, stiff stem.

Maman Cochet. This is the famous pink Cochet. Light pink shaded with salmon-yellow, outer petals splashed with light rose; extremely large and full ; fine for cut flowers; needs to be well protected in winter.

White Maman Cochet. A sport from Maman Cochet with creamy-white flowers, faintly tinged with blush; long and pointed buds opening to large flowers; an exceedingly pretty and valuable variety. Needs good winter protection.

La France. Silvery rose with pink shades and satin-like petals of unsurpassable beauty; large symmetrical and deliciously fragrant; blooms from June until frost.

Kaiserin Augusta Victoria. Pure white, does not pink when planted out; splendid, large buds and superb, full, double blooms, making the choicest cut flowers. A most sturdy grower, blooming from early spring until late frosts. 


\section{_Hybrid Perpetual or June Flowering Roses}

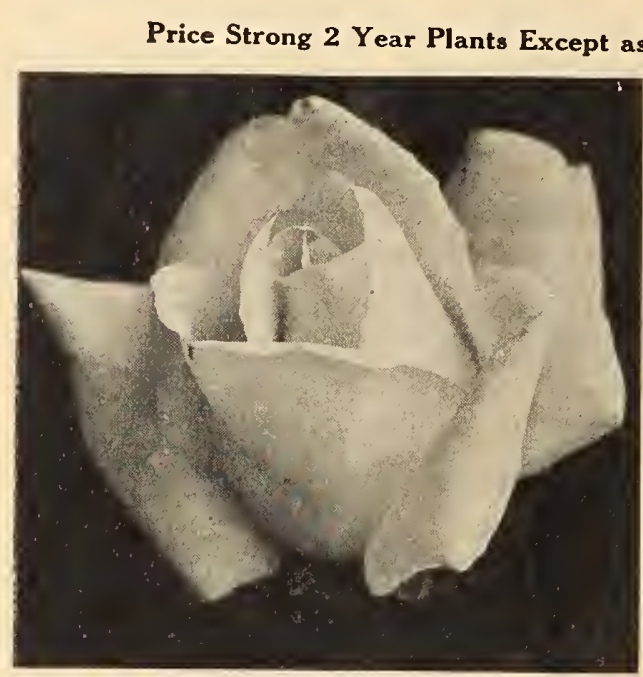

FRAU KARL DRUSCHKI

Prince Camille de Rohan. Universally known as "The Black Rose" owing to its very deep, velvety crimson color, passing to intense maroon, and shaded black; large handsome and fragrant blooms.

Ulrich Brunner. Cherry-red, of immense size; fine form, and effective in the garden.

Soliel d' Orr. Gold and orange yellow, varying to ruddy gold. $35 \mathrm{c}$ each.

Persian Yellow. Deep golden yellow, semidouble. An old favorite.

Red Moss (Henri Martin.) Large full flowers of deep red; well mossed; fragrant.

White Moss. (Countess of Murinais) Pure white flower, buds very heavily and beautifully mossed.
EACH

.40
IEN

$\$ 3.50$

Anna de Diesbach. Bright deep clear pink of largest size; fine bud and open flower.

Clio. Flesh color, shaded in the center to rose-peach. Large fine, globular form; free bloomer and distinct.

Coquette des Alps. Pure white, delicate tinted blush on first opening.

Frau Karl Druschki. This grand white Rose has become renowned as the very highest type of its class and the best snow-white Rose ever introduced. It is an extraordinarily strong grower, and has the vigor and hardiness of an oak. The magnificent flowers are nothing less than gorgeous; immense in size and produced with great freedom. A true snow-white and the standard by which all other whites are judged.

Margaret Dickson. White, with delicate blush center; large and of good substance.

Marshall P. Wilder. Deep, rich glowing red.

General Jacqueminot. Crimson-scarlet; large, full; very fragrant; excellent.

American Beauty. - A well known red forcing rose. At its best in the greenhouse. 35c each.

Madame Plantier. Extremely hardy; vigorous grower; pure white; sweet scented.

Hugh Dickson. A vigorous free grower and perpetual bloomer; brilliant crimson shaded scarlet; large and fine form; sweetly scented.

Magna Charta. Bright rose, very large and double, of good form and fragrance.

Mrs. John Laing. Clear bright shining pink full and double; perfectly hardy with immense flowers.

Paul Neyron. Deep rose, flowers of immense size; claimed to be the largest Rose grown.

\section{Tree Roses}

The Tree Roses are grafted on hardy Rose stalks four to five feet high, and when in full bloom are objects of beauty, making handsome plants for the law or Rose border. In this shape we offer only the Hybrid Perpetual and hardy classes. We have them in white, the different shades of pink, red and crimson. Fine, strong trees that will bloom nicely the first year. $\$ 1.00$ each.

\section{Hardy Ramblers and Climbers}

\section{Price Except as Noted 40 c Each, $\$ 3.50$ per 10}

Climbing American Beauty. This new climbing form of the famous pink rose so long the favorite for cutting, is as lovely and fragrant and deep pink as the bush form. The hardy climbing wood with which it is crossed gives healthy, perfect foliage and a strong climbing habit of growth; one plant of this variety will produce twenty times as many flowers as the old American Beauty.

Crimson Rambler. Bright crimson flowers produced in large clusters of pyramidal form; grand variety for pillars and arches and to train over porches; also makes a fine attractive hedge.

Dorothy Perkins. A most beautiful deep pink; the flowers are borne in large clusters of small double blooms and are very sweetly scented. The strongest and most satisfactory of the rambler or climbing class.
Flower of Fairfield. A counterpart of Crimson Rambler in every respect, except that it shows everblooming tendencies, many new growths being terminated with large clusters of flowers.

Tausendschoen. The flowers upon first opening are the most delicate shade of pink ever seen in a Rose, the bright clusters of blossums almost covering the handsome pale green foliage. A vigorous hardy climber with few thorns, of German origin.

Blue Rambler. A German novelty of recent introdcution, the nearest approach to a blue rose.

Yellow Rambler. A hardy climber. Double golden-yellow flowers in large clusters.

White Rambler. Grows vigorously in clusters of pure white flowers. 


\section{Baby Rambler Roses}

Crimson Baby Rambler. This is the original Baby Rambler. It is in bloom all the time, flowers in large clusters of brightest crimson. It grows to a height of eighteen inches and hides the plant with its bloom. A most wonderful rose. $40 \mathrm{c}$ each ; 83.50 per 10

White Baby Rambler. Flowers large, fully double, numerous, beautiful creamy

white, merging to a center of clear bright pink. This variety is a favorite and one of the best of all bedding roses. $40 \mathrm{c}$ each $\$ 3.50$ per 10.

Pink Baby Rambier. A true dwarf form of Dorothy Yerkins. The flowers are a shiny brilliant pink, produced in the greatest profusion in large clusters. $40 \mathrm{c}$ each : $\$ 3.50$ per 10

\section{DIRECTIONS FOR TRANSPLANTING}

Preparation of Soil and Stock-Prepare a rich deep bed of mellow soil and have the land sufficiently drained to relieve the roots from standing water. To insure a fine growth land should be in good condition as is required for a crop of wheat, corn or potatoes. We use great care in digging and packing, but the loss of some small roots and fibers is unavoidable. If the stock is properly prepared before it is planted, no pernanent injury will result from this, but to preserve the natural balance between the top and root, the former should be cut back to about one-half of the previous year's growth. Prune off all bruised or broken roots; a smooth cut will callous sooner than a broken end. Peach trees should have all the side branches trimmed off before planting. Evergreens and other ornamentals, the beauty of which depends on preserving their natural form, should be trimmed very little if any. If not ready to plant when the trees arrive, put them in a trench covering the roots well with mellow earth and packing it down.

Planting-Make the holes large enough to admit the roots without cramping or bending and deep enough to set the trees to their natural depth. Fine surface soil should be used for covering the rcots, and this should be carefully worked among them. If the ground is dry, it is well to pour in some water when the hole is partially filled. See that the ground is firmly and solidly packed over all parts of the roots, so that there will be no opportunity for dry air or frost to enter and destroy roots deprived of the full benefit of their natural protection. Omission to pack the earth solidly is the most frequent cause of failure in plantingnursery stock. Fill the holes full enough to be even with the surrounding surface after the fresh earth settles. Always remove the labels when planting. If these are left until the trees are grown, the connecting wire often cuts into and destroys the tree or branch to which it is attached. Never use manure in contact with roots. When planting dwarf trees, set them low enough to cover the stock upon which they are budded. Large standard trees should be staked and tied, so that the wind will not loosen the roots. This should be done so that the bands will not chafe the trees. A very good plan is to drive two stakes, and confine the trees between straw or hay bands, stretched from stake to stake. It is not necessary to stake medium-sized trees that have been properly cut back when transplanted.

Mulching-When trees or bushes are planted, they should be mulched or covered with a layer of coarse nisnure or litter from 3 to 6 inches deep, over a space two fect wider than the extent of the roots. This kecps the earth moist and of even temperature.

after Planting-Grass should not be allowed to grow about young trees or plants. The ground should be cultivated for a space of at least one foot beyond the roots. If the ground is poor it should be enriched with a surface application of manure. Pruning should be varied according to the condition of the tree and purpose of tile planter. It should be done regularly every spring, before the buds swell. In this way the removal of large branches will be avoided.

Injured Trees-If trees are received in a frozen state, place the package unopened in a cellar away from frost and heat, until thawed out, and then unpack. If partially dried from long exposure, bury entirely in the ground, or place in water from twclve to twenty-four hours. There is a popular belief that trees are in great danger if more than a week or two in transit. Now if the trees are properly ripened and properly packed, they will carry safely for several months in modcrately cool weather. We have had seedlings sent from France that were three months in the boxes and came out in perfect condition. This knowledge may afford some relief to the over-anxiety of exparienced buyers.

\section{Number of Trees or Plants per Acre}

40 feet apart 35 feet apart

30 feet apart

25 feet apart

20 feet apart

18 feet apart

15 feet apart

12 feet apart

10 feet apart

8 feet apart

6 feet apart

5 feet apart

4 feet a part

3 feet apart

2 feet apart

1 foot apart
Square Method Triangular Biethod

27 trees

35 trees

50 trees

70 trees

110 trees

125 trees

305 trees

435 trees

680 trees

1,210 trees

1,745 trees

2,722 trees

4,810 trees

10.890 trecs

43,560 trees
31 trees

40 trees

55 trees

80 trees

125 trees

155 trees

225 trees

350 trees

595 trees

775 trecs

1,600 trees

2,010 trees

3,145 trees

5,590 trecs

12,575 trees

50,300 trees
195 trees

\section{Suitable Distances for Planting}

Apples, Standard

Apples, Dwarf

Pears, Standard

Pears, Dwarf

Peaches and Apricots

Cherries, Sweet

Cherries, Sour

Plums

Quinces

Grapes

Currants

Gooseberries

Raspberries

Blackberries

Strawberries

Asparagus, in beds

Asparagus, in fields
30 to 40 feet

8 to 10 feet

18 to 20 feet

10 feet

16 to 18 feet

18 to 20 feet

15 to 18 feet

16 to 20 feet

10 to 12 feet

8 to 10 feet

3 to 4 fcet

3 to 4 feet

3 to 4 feet

5 to 7 feet

$11 / 2$ by $11 / 2$ feet

1 by $1 \frac{1}{2}$ feet 1 by 3 feet 


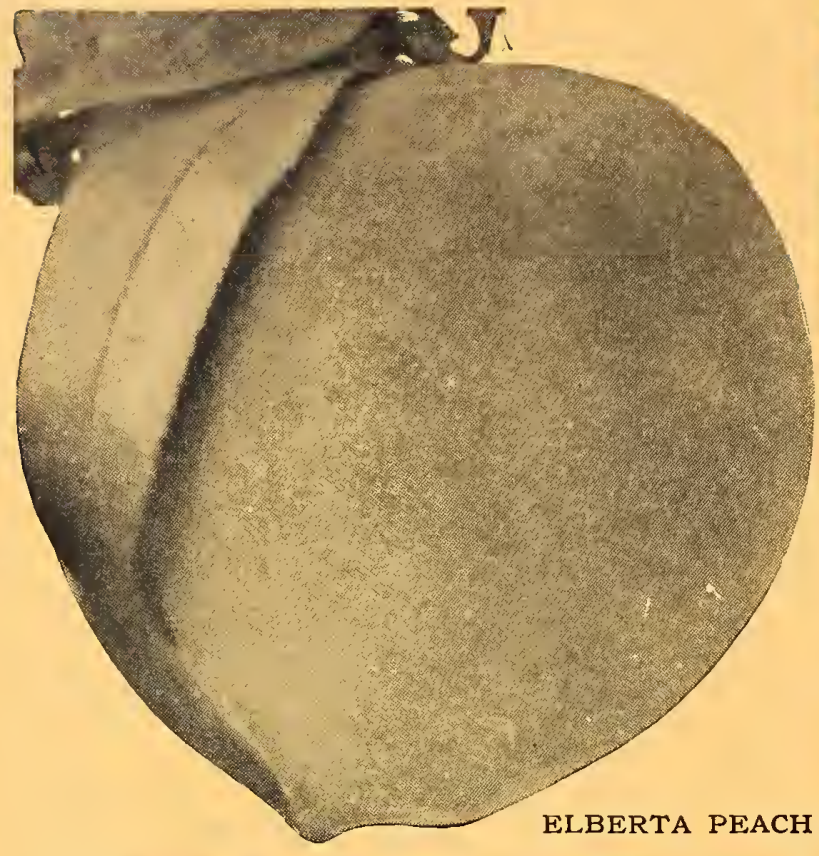

\section{One Each of These 5 Fine Fruits in Different Collections as Follows}

Bearing Age Size for $\$ 2.25$ XXX Size for 1.60 XX Size for 1.30 $\mathrm{X} \quad$ Size for 1.00

In sections where Peach are not hardy, we will supply Wealthy Apple instead if requested; no other change.

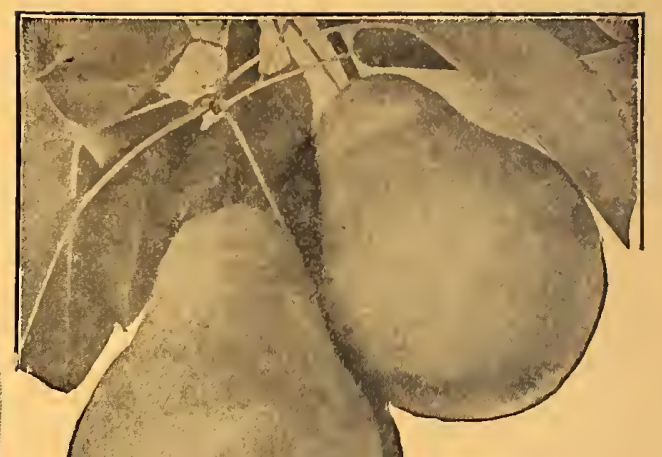

BARTLETT

PEAR

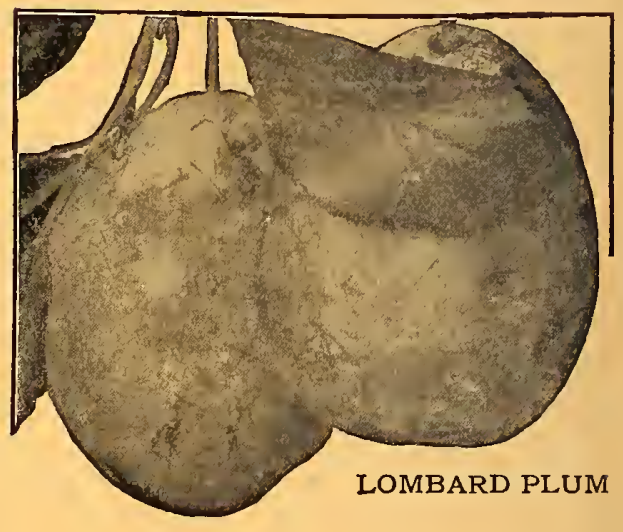

Tुe William J. Reilly Wholesale Nurseries DANSVILLE, N. Y.
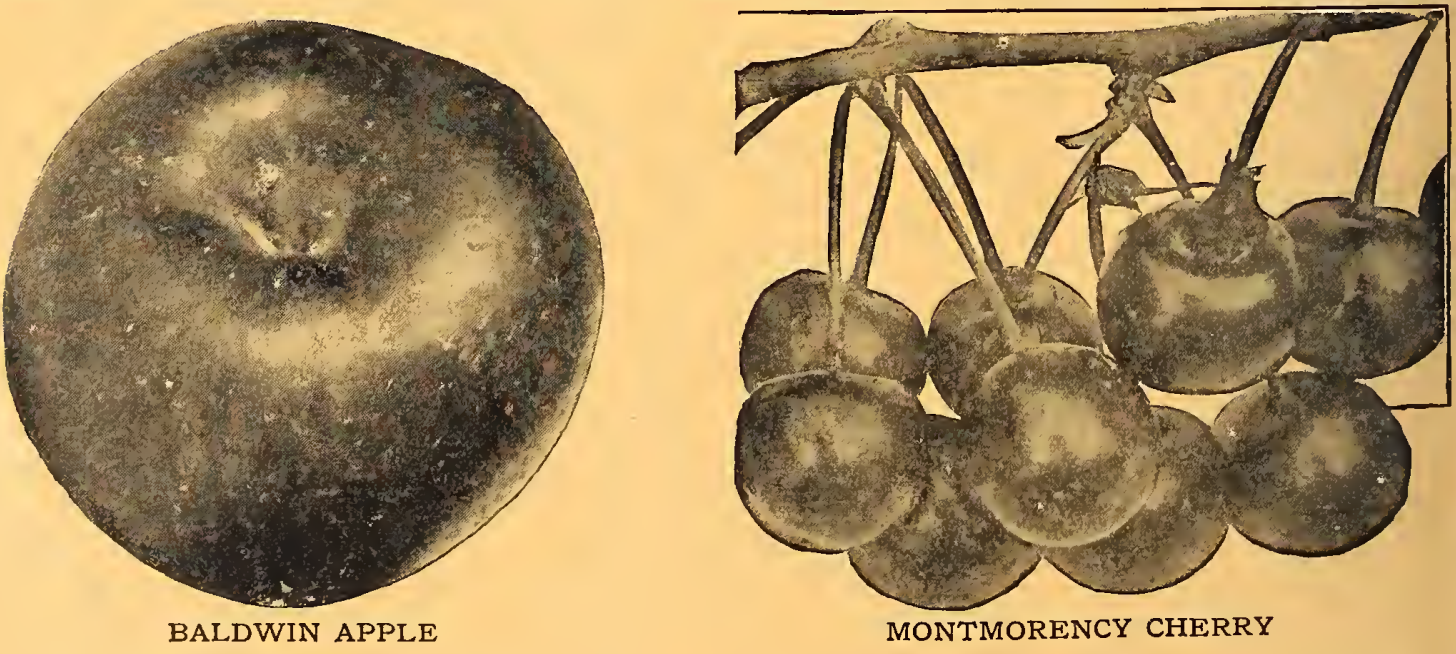